\title{
Zasady opisu geograficznego i rysowania map w Geografii Ptolemeusza redagowanej przez Nicolausa Germanusa - rękopis BOZ 2*
}

\section{Lucyna Szaniawska}

D ziewiętnastowieczny badacz historii Joachim Lelewel pisząc o rozwoju myśli geograficznej ubolewał, że „ze starożytnych krajobrazów pozostały tylko przeróbki Ptolemeja i przeróbki drożników Rzymskich" "', a inne graficzne prezentacje ekumeny poszły w zapomnienie. Do dzisiaj należy odnotować znaczny postęp badań kartografii starożytnych Rzymian i Greków, ale ale mamy wciąż niewiele informacji o innych dokumentach kartograficznych. Najwięcej stron poświęcono omówieniu kopii rękopiśmiennych lub drukowanych tekstu Geografii aleksandryjskiego uczonego Klaudiusza Ptolemeusza ${ }^{2}$ oraz treści jego map. Komentatorzy i badacze, poczynając od prac studyjnych w XIX w., głównie skupili się na wykazywaniu popełnionych przez uczonego aleksandryjskiego błędów. W drugiej połowie pierwszej dekady XXI w. powstało kilka monografii i artykułów przytaczających a także analizujących dane geograficzne zapisane w tekście i na mapach przez Ptolemeusza. Najobszerniejsze z nich to wyniki badań A. Stückelbergera i F. Mittenhubera oraz innych, publikowane w Bazylei w latach 2006 i 2009. Mimo wielu opracowań, sporo zostało jeszcze do zrobienia. Niniejszy artykuł jest przyczynkiem, „kamyczkiem” dorzuconym do zbioru prac analizujących oraz krytykujących aleksandryjski traktat.

*Syntetyczna informacja o traktacie geograficznym Ptolemeusza w redakcji Nicolausa Germanusa napisana przez autorkę ukazała się w: Świat Ptolemeusza, włoska kartografia renesansowa w zbiorach Biblioteki Narodowej. Wystawa w stulecie urodzin Jana Zamoyskiego, Warszawa 2012, s. 72-83.

${ }^{1} J o a c h i m a$ Lelewela badania starożytności we względzie geografji: część naukowa, Wilno-Warszawa 1818, s. 3.

${ }^{2}$ Klaudiusz Ptolemeusz (ok. 100-168), astronom i geograf, Grek pochodzący z Tebaidy (region w Egipcie), który jako obywatel rzymski działał w Aleksandrii.

${ }^{3}$ Zbiór kilkudziesięciu map wg Ptolemeusza w: Strabonis nobilissimi et doctissimi philosophi ac geographi Rervm geographicarum commentarii
Geograficzna wiedza starożytnych Greków, takich jak Homer, Anaksymander, Demokryt, Herodot, Arystoteles, Eratostenes, Hipparch, Posejdonios, Pomponiusz Mela, Strabon, prawdopodobnie zginęłaby bezpowrotnie pod naporem najeźdźców ze wschodu, gdyby nie przybywający do Rzymu od II w. n.e. emigranci greccy, a wśród nich retorowie i filozofowie. Także Rzymianie, zajmując na południu Italii liczne kolonie greckie, przejmowali dziedzictwo Greków i stopniowo odkrywali spuściznę ich wiedzy antycznej. Najdawniejsze zachowane kopie starożytnych dzieł, wykonane w wiekach VIII do XI, przekazują wiedzę o Ziemi głównie w formie słownej, zaś kopiowanie traktatów geograficznych, np. Strabona $^{3}$ czy Pomponiusza Meli ${ }^{4}$ miało w dobie renesansu drugorzędne znaczenie dla rozwoju prezentacji ekumeny, o czym świadczą nieliczne edycje tych nie dość precyzyjnych opisów geograficznych oraz załączane do nich przez wydawców mapy ptolemejskie lub innego pochodzenia ${ }^{5}$. Obrazy graficzne, narysowane przez mnicha greckiego i tłumacza Maximosa Planudesa oraz późniejsze, wykonane w 1415 r. przez Francesco di Lapacino i Domenico di Leonardo Boninsegini, towarzyszą kopiom dopiero od końca XIII wieku. Do dzisiaj zachowało się 17 takich kopii, a wśród

libris XVII contenti, Latini facti Gvilielmo Xylandro Augustano interprete adiecimvs eivsdem annotativncvlas (...), accesserunt inventaria locvpletissima rerum et uerborum memorabilium, atq[ue] scriptorum, quorum sententias allegat Strabo, Basileae: ex Officina Henricpetrina, 1571.

${ }^{4}$ Mapa świata wg Ptolemeusza w: Pomponij Mellae Cosmographi Geographia: Prisciani quoq[ue] ex Dionysio Thessalonicensi de situ orbis interpretatio. Pomponij Mellae de orbis situ Liber primus. Prooemium, Venetijs: Erhardus Ratdolt Auguste[n]sis impressit, 1482.

${ }^{5}$ Mapa świata Petrusa Apianusa w: POMPONII MELAE DE ORBIS SITV LIBRI TRES, ACCVRATISsime emendati, una cu[m] comme[n]tariis loachimi Vadiani Heluetii castigatioribus, et multis in locis auctioribus factis (...), Basileae: apud Andream Cratandrum, 1522. 
nich najczęściej cytowane kodeksy znajdują się w klasztorze Vatopedi na górze Athos, w Bibliotece Watykańskiej - Vat. Gr. 177 oraz w Muzeum Topkapi Sarayi w Stambule - Codex Seragliensis Gr. 57 z mapami przypisywanymi Maximosowi Planudesowi ${ }^{6}$.

Po przetłumaczeniu traktatu na łacinę przez ucznia Manuela Chrysolorasa ${ }^{7}$, florentyńczyka Giacoma da Scarperia (łac. Jacobus Angelus) przed rokiem $1410^{8}$ zainteresowanie traktatem z oczywistych przyczyn znacznie wzrosło i dało asumpt do kolejnych prac redakcyjnych, początkowo przede wszystkim we włoskich ośrodkach uniwersyteckich. Wkrótce Geografia Ptolemeusza stała się podręcznikiem rysowania nowoczesnych, jak na początek XV wie$\mathrm{ku}$, map ekumeny. Jednak dopiero w drugiej połowie XV w. działający w Rzymie i Florencji ${ }^{9}$ Nicolaus Germanus zaopatrzył Geografie w mapy zredagowane w nowatorski sposób ${ }^{10}$, co spowodowało powszechne $\mathrm{w}$ świecie nauki jej zrozumienie i uznanie.

Do końca XVII wieku wykonano kolejnych 38 rękopiśmiennych kopii edycji Geografii oraz 45 drukowanych z mapami ${ }^{11}$. Pierwsze, tłoczone z drewnianych klocków lub miedzianych płyt mapy były włączane do edycji Geografii we włoskich ośrodkach: Bolonii (1470), Rzymie (1478) i Florencji (1482). Drukowane wersje tego dzieła przechowywane są, nieraz w kilku egzemplarzach, praktycznie we wszystkich europejskich bibliotekach narodowych i większych zbiorach uniwersyteckich, a także - w zasobniejszych światowych.

\footnotetext{
${ }^{6}$ L. Szaniawska, Sarmacja na mapach Ptolemeusza w edycjach jego Geografii, Warszawa 1993, s. 18-19.

${ }^{7}$ Grek urodzony w Konstantynopolu, uczący greki i literatury greckiej na Uniwersytecie we Florencji na przełomie XIV i XV w.

${ }^{8}$ Tłumaczenie zawiera dedykację dla papieża Aleksandra V z datą 1410

${ }^{9}$ Clavdii Ptolemaei Geographiae codex Vrbinas graecus 82: Tomvs prodromvs Josephi Fischer, S.J., De Cl. Ptolemaei vita, operibvs, geographia praesertim eivsque fatis. Pars prior. Commentatio. Lvgdvni Batavorvm, apud E.J. Brill; Lipsiae, apud Ottonem Harrassowitz, 1932, w: Codices e Vaticanis selecti; 19.2 v. w 4 (635 s.) s. XV, 251-352 autor uważa, że Nicolaus stworzył trzy redakcje traktatu, różniące się interpretacja ptolemejskich reguł i danych; L. Szaniawska, Sarmacja na mapach Ptolemeusza w edycjach jego "Geografii”, s. 20-22, stosując inne kryteria, wyróżnia sześć wersji redakcji map zawartych w Geografii.

${ }^{10}$ Według J. Babicz, The Celestial and Terrestrial Globes of the Vatican Library Dating from 1477, and their Maker Donnus Nicolaus Germanus
}

\section{Kopie Geografii wykonane przez Nicolausa Germanusa}

Nicolaus Germanus działał we Włoszech, gdzie tworzył księgi na zamówienie księcia Borsa d'Este, później - dla papieża Pawła II $^{12}$. Zachowało się niewiele dokumentów mówiących o jego życiu. Jeden z wcześniejszych komentatorów Geografii Ptolemeusza, Martin Georg Raidel, w wydanej w Norymberdze w 1737 r. publikacji Commentatio critico-literaria de Claudii Ptolemaei Geographia eiusque codicibus tam manuscriptis quam typis expressis (...) nazywa Nicolausa autorem map, przytacza za wcześniejszym dziełem Jana Trithemiusa Catalogus Virorum litteris illustrium, wydanym we Frankfurcie w 1601 roku, informacje o nim: „Donnus Nicolaus, benedyktyn z klasztoru, jak powiadają, w Reichenbach, mąż uczony w naukach świeckich, któremu nieobce były pisma teologiczne, wybitny filozof i astronom, niestrudzony redaktor Kosmografii Ptolemeusza i sumienny odnowiciel, wyróżniający się umysłem jasnym w wykładzie. Napisał księgi, których nie można pominąc i którymi zapisał się w pamięci potomnych. Wśród nich wymienić należy dzieło godne podziwu i bardzo cenione - Kosmografię Ptolemeusza, zawierające VIII ksiąg, z malowidłami i wytwornie ozdobione nowymi mapami, dedykowane papieżowi Pawłowi II (...). Żył za cesarza Fryderyka III i papieża Pawła II w roku $1470 " 13$.

$\mathrm{Z}$ zachowanych dokumentów wiadomo między innymi, że książę Borso d'Este w liście

(ca. 1420-ca. 1490), „Der Globusfreund”, 1987, nr 35-37, s. 161 żyjącego w latach ok. 1420-1490, pochodzącego z Reichenbach w Dolnej Austrii (stąd jego przydomek „Germanus”).

${ }^{11}$ L. Szaniawska, „Geografia” Ptolemeusza prekursorskim zbiorem danych przestrzennych, w: Bazy danych w kartografii, red. W. Żyszkowska, W. Spallek, Wrocław 2009, s. 132.

2 J. Babicz, Donnus Nicolaus Germanus: Probleme seiner Biographie und sein Platz in der Rezeption der Ptolemäischen Geographie, München 1980, s. 31-39; Die Ulmer Geographia des Ptolemäus von 1482. Zur 500. Wiederkehr der ersten Atlasdrucklegung nördlich der Alpen, Ausstellung und Katalog: K.H. Meine; Ulm, Schwörhaus 11. Oktober bis 30. November 1982, Weißenhorn 1982, s. 19-21.

${ }^{3}$ G.M. Raidel, Commentatio critico-literaria de Clavdii Ptolemaei Geographia, eivsque codicibvs tam manvscriptis qvam typis expressis, conscripta a Georgio Martino Raidelio (...). Norimbergae: typis et sumptibus haeredum Felseckerianorum, 1737, s. 31-33. 
z 30 marca 1466 r. do Ludovica Casella, referendarza i prywatnego doradcy, poleca wypłacenie Nicolausowi 100 złotych dukatów za wspaniałą księgę Kosmografia, a w liście z 8 kwietnia 1466 r. - 30 złotych guldenów za pięknie wykonaną Kosmografię oraz inne prace ${ }^{14}$. Jest to informacja o pierwszej z zachowanych kopii Geografii Nicolausa (obecnie przechowywanej w Modenie), która jeszcze nie zawiera żadnej spośród tabulae modernae ${ }^{15}$. Warszawska kopia w rękopisie Biblioteki Narodowej BOZ $2^{16}$, posiadająca trzy dodane tabulae modernae: Hiszpanii, Europy Północnej i Italii, została wykonana przez Nicolausa przypuszczalnie później, jednak wcześniej niż kopie zawierające, oprócz już wymienionych map, także mapy Palestyny i Galiii ${ }^{17}$, podobnie jak warszawska kopia dedykowane papieżowi Pawłowi II. Jedna $\mathrm{z}$ tych kopii, przechowywana na zamku w Wolfegg, zawiera datę jej ukończenia: „scripsit Florentiae finivitque Octubr[is] 4, 1468"18. Na tej podstawie warszawską kopię można uważać za wykonaną po marcu 1466 , a przed październikiem 1468 roku. Tradycyjnie datowanie BOZ 2 (na około 1467 r.) przyjmuje się za informacją zapisaną na papierowej karcie ochronnej w dodanym do traktatu tytule ${ }^{19}$.

Do dzisiaj zachowało się w bibliotekach dwadzieścia ${ }^{20}$ przypisywanych Nicolausowi rękopiśmiennych kopii zbiorów map ptolemejskich, z czego tylko kilka sygnowanych jego imie-

\footnotetext{
${ }^{14} \mathrm{~J}$. Babicz, The Celestial and Terrestrial Globes of the Vatican Library Dating from 1477, and their Maker Donnus Nicolaus Germanus (ca. 1420-ca. 1490), „Der Globusfreund”, 1987, nr 35-37, s. 161; L'Atlante di Borso D'Este. La Cosmographia della Biblioteca Estense Universitaria di Modena, commentario all'edizione in facsimile del codici miniato cl.X.1.3 = Lat. 463, testi di Laura Federzoni, Annalisa Battini, a cura di Mauro Bini. Modena: II Bulino edizioni d'arte, 2006, s. $25,34-35$.

${ }^{15}$ Nicolaus Germanus, Kopia Geografii, Modena, Biblioteca Estense Universitaria, Lat. 463 [dalej: Modena, BE], zob. ryc. 1c.: dedykacja księciu.

${ }^{16}$ Od drugiej połowy XIX w. kodeks jest powszechnie odnotowywany w światowej literaturze jako Codex in Bibliotheca Zamoiskiensi Varsoviae conservatus. Nazwę tę upowszechnił szwedzki geograf i kolekcjoner A.E. Nordenskiöld, po raz pierwszy wspominając 0 kodeksie w 1889 r. w: A.E. Nordenskiöld, Facsimile Atlas to the early history of cartography. with reproductions of the most important maps in the XV and XVI centuries, translated from the Swedish original by J.A. Ekelof and C.R. Markhaln, reprint $z$ wyd. Stockholm 1889, New York 1973, s. 61, tabl. XXX. Zaś według Clavdii Ptolemaei

Geographiae codex Vrbinas graecvs 82, s. XV - L 21 Codex Zamoiskianus Latinus (Varsoviae).

${ }^{17}$ L. Szaniawska, Sarmacja na mapach Ptolemeusza, s. 21-22, są to kopie Geografii: Codex Wolfeggianus Latinus oraz Codex Laurentianus Latinus XXX, 4.

${ }^{18}$ Clavdii Ptolemaei Geographiae codex Vrbinas graecvs 82, s. 356

${ }^{19} \mathrm{Nad}$ złoto droższe. Skarby Biblioteki Narodowej, red. H. TchórzewskaKabata, Warszawa 2000, s. 68.

${ }^{20}$ Clavdii Ptolemaei Geographiae codex Vrbinas graecvs 82, s. XIV-XV; Die Ulmer Geographia 1982, s. 19-21.

${ }^{21}$ Florencja, Biblioteca Medicea Laurenziana, Plut. 30.03 (w literaturze: Plut. XXX, 3), [dalej: Florencja, BML].

${ }^{22}$ Watykan, Biblioteca Apostolica Vaticana, Urb. Lat. 274, [dalej: Watykan, BAV].

${ }^{23}$ Modena, BE.

${ }^{24}$ Warszawa, Biblioteka Narodowa, BOZ 2, [dalej: Warszawa, BN].

${ }^{25}$ Florencja, Biblioteca Medicea Laurenziana, Plut. 30.04 (w literaturze: Plut. XXX, 4), [dalej: Florencja, BML, Plut. 30.04].

${ }^{26} \mathrm{Neapol}$, Biblioteca Nazionale, V, F 32, [dalej: Neapol, BN].

${ }^{27}$ Nowy Jork, Public Library, MA 097, [dalej: Nowy Jork, NYPL].
}

niem. Jako wyjątkowo cenne można wymienić: Codex Florentinus Laurentianus Plut. $30.03^{21}$, Codex Vaticanus Urbinas Latinus 27422, Codex in Bibliotheca Estense Universitatis Latinus $463^{23}$ oraz Codex in Bibliotheca Zamoiskiensi Latinus BOZ $2^{24}$, a także najpóźniejszą z nich, wykonaną przed $1480 \mathrm{r}$ - - z pozostawionym miejscem na dedykację i niedokończonym rysunkiem map - kopię Codex Florentinus Laurentianus Plut. 30.0425. Większość pozostałych - np. kopie przechowywane w Bibliotece Narodowej w Neapolu (Codex Neapolitanus Latinus V, F 32$)^{26}$ i w Bibliotece Publicznej w Nowym Jorku (Codex Ebnerianus Latinus NYPL MA 097) ${ }^{27}$ - to wersje niezawierające imienia Nicolausa w dedykacji lub incipicie (ryc. 1). Kopia neapolitańska rozpoczyna się słowami: „PROLOGVS JACOBI ANGELI FLORENTINI IN TRASLATIONEM COSMOGRAPHIAE CLAVDII PTOLOMAEI ALEXANDRINI”, dalej następuje ozdobny inicjał litery „A”, rozpoczynający tekst „AD TEMPORA claudii ptolomei uiri alexandrini cogitanti ut (...)". Całość została prawdopodobnie tak skomponowana, by zastąpić literę „N” (Nicolausa) literą „A” (Angelusa), o czym może świadczyć kopia Florencja, BML, Plut. 30.04 - niedokończona i bez dedykacji. Pierwsza karta na recto i na verso nie ma żadnych napisów, jedynie ozdobny inicjał litery „N" (ryc. 1d). Jej tekst, rozpoczynający się od pierwszej księgi Ptolemeusza na karcie 2r, zapi- 


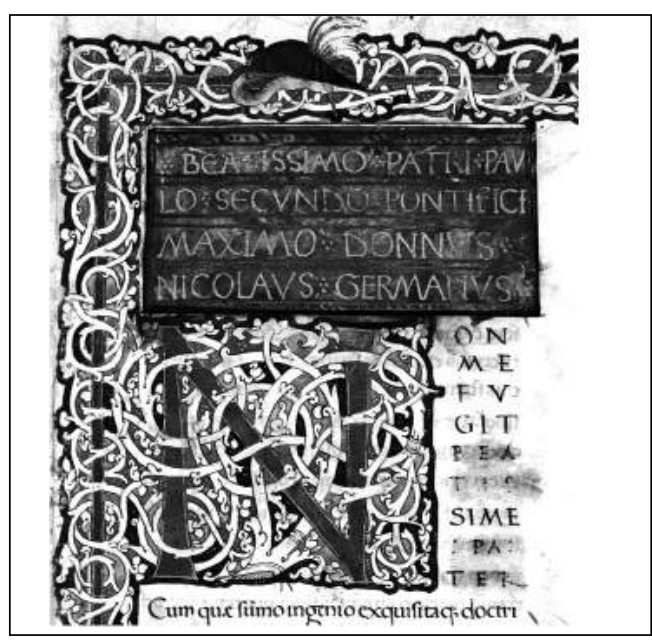

(a)

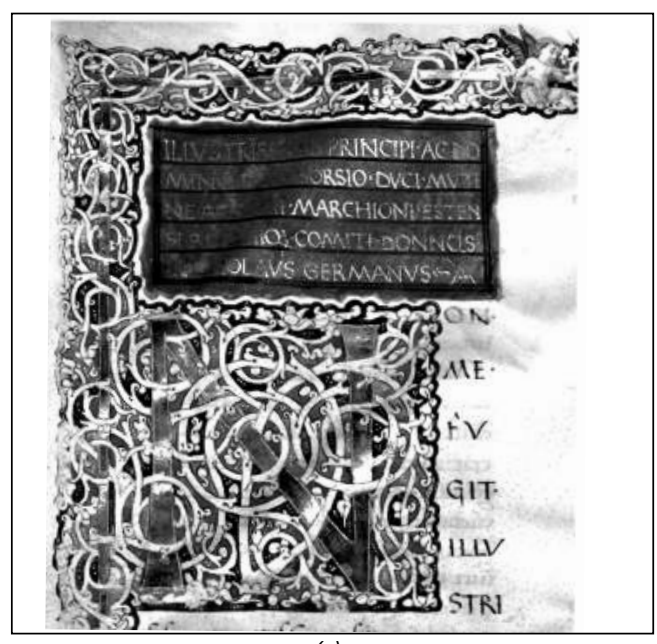

(c)

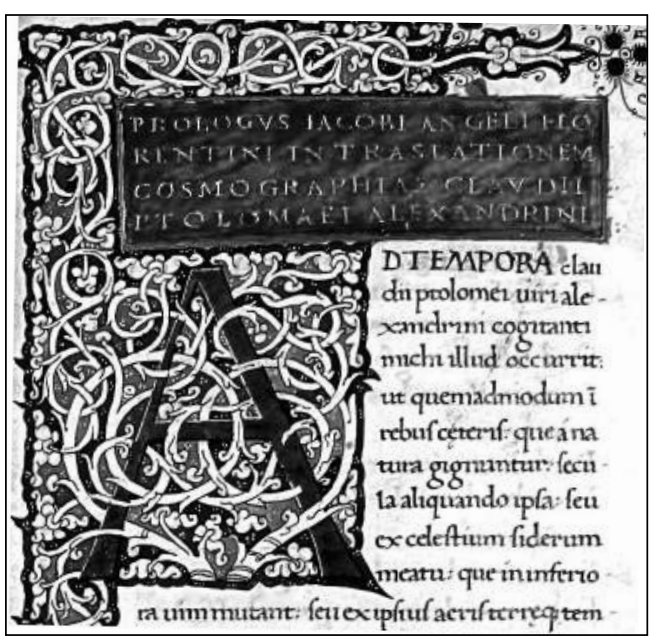

(b)

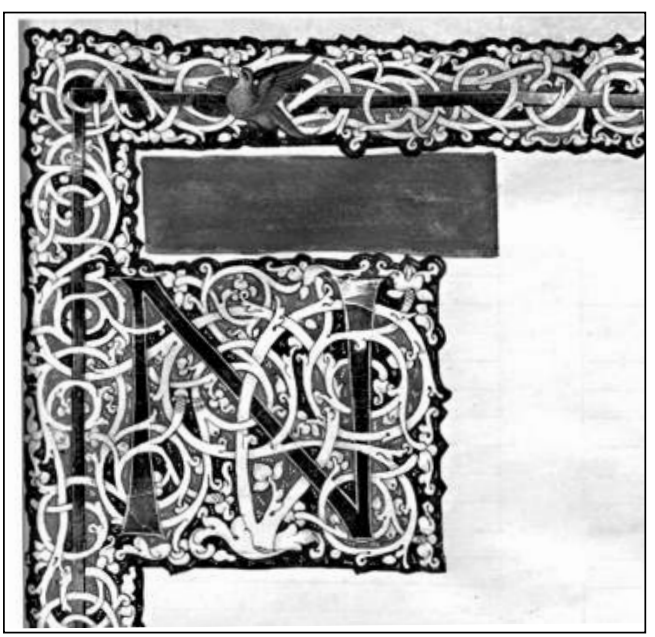

(d)

Ryc. 1. Dedykacja lub prolog wraz z inicjałami w „Geografii” Ptolemeusza w kopiach: (a) Warszawa, BN; (b) Neapol, BN; (c) Florencja, BML; (d) Florencja, BML, Plut. 30.04 (bez dedykacji)

sany został bez wątpienia ręką Nicolausa. Mapy, pomimo że są niedokończone, były narysowane także przez niego.

Kopii Geografii w rękopisie Biblioteki Narodowej w Warszawie, oznaczonej sygnaturą BOZ 2, towarzyszy zapisany w XIX wieku tytul: $C O$ SMOGRAPHIA Claudii PTOLOMAEI Alexandrini Mathematicorum Principis, Seculo secundo, scilicet circa Annum a Nativitate Domini nostri Iesu Christi Centesimum Trigesimum octavum, sub Antonino Pio Imperatore Romano florentis, manu Donni Nicolai Germani Presbyteri secula- ris descripta, Tabulisque egregie pictis adornata, ac Paulo secundo, Summo Pontifici, ab eodem circa Annum 1467 dedicata $^{28}$. Część pierwsza zawiera tekst na 80 kartach (I-VII, 1-43, 43a, 44-72) o wymiarach $41,5 \times 30,5 \times 2,7 \mathrm{~cm}$. Druga część składa się z 30 tablic o wymiarach $41,5 \times 58 \mathrm{~cm}$. Rękopis, dedykowany około 1467 r. papieżowi Pawłowi II (1464-1471), był w XVI wieku własnością kanclerza i het-

\footnotetext{
${ }^{28}$ Zapis na papierowej karcie ochronnej dodanej w trakcie XIX-wiecznej konserwacji obiektu.
} 
mana wielkiego koronnego Jana Zamoyskiego. Przekazany później Akademii Zamojskiej, trafił do zbiorów Biblioteki Ordynacji Zamojskiej, a obecnie jest przechowywany jako depozyt w Bibliotece Narodowej w Warszawie ${ }^{29}$.

\section{Tekst Geografii zapisany przez Nicolausa Germanusa w BOZ 2}

Traktat składa się z dwóch odrębnych części tekstu i zbioru map, które w XIX wieku oraz w 2005 r. zostały poddane zabiegom konserwatorskim. Część tekstową traktatu tworzy jeden wolumin składający się z 73 zapisanych pergaminowych kart o wymiarach $41,5 \times 30,5 \mathrm{~cm}$, pokrytych minuskułą renesansową zapisaną brązowym atramentem, w dwóch kolumnach, zawierających średnio po 44 wiersze na stronie. Tekst główny, zdobienia inicjałów, a także teksty na verso map i napisy na mapach są wykonane ręką jednego kopisty ${ }^{30}$, prawdopodobnie Nicolausa Germanusa ${ }^{31}$. Pierwszą księgę Geografii Ptolemeusza poprzedza karta zawierająca dedykację dla papieża Pawła II (ryc. 1a) „BEATISSIMO PATRI PAVLO SECVNDO PONTIFICI MAXIMO DONNVS NICOLAVS GERMANVS” wraz z inicjałem „N” rozpoczynającym tekst listu dedykacyjnego „NON ME FVGIT BEATISSIME PATER (...)”, w którym Nicolaus zwraca się do papieża: „Ojcze święty. Gdy w tym, co - dzięki najwyższym zdolnościom i wyśmienitej wiedzy - namalował Ptolemeusz Kosmograf, zamierzaliśmy coś zmienić i odświeżyć, spodziewaliśmy się, że ta nasza praca natrafi na zarzuty wielu osób. Wszyscy bowiem, zwłaszcza niedoświadczeni w obliczeniach geometrycznych, którzy uważają, że nasze obrazy znajdujące się w mapach, które do Ciebie wysłaliśmy, są nieco niezgrabne, z pewnością mogą oskarżyć nas o brak doświadczenia lub zuchwałość (...)"32.

We wprowadzeniu Nicolaus mówi o ogólnych zasadach geografii sformułowanych przez aleksandryjskiego uczonego, o Ptolemei pictura - jego obrazowaniu świata przy zastosowaniu reguł geometrycznych, np. do rysowania linii długości geograficznej (linearum longitudinalium). Następnie informuje o włączeniu nowych map: „Duas nobilissimas regiones
Hispaniam videlicet \& Italiam (...)”, a także „regiones que in Occeano Sarmatico (...) Datiam utpote Scaniam Norbegiam Gottiam Suetiam Gronelandiam et regiones sibi adherentes (...)" - obszarów, które zostały pominięte przez Ptolemeusza i Strabona.

Księga pierwsza, i kolejne sześć, to tekst Ptolemeusza, który, jak należy się spodziewać, został przez Nicolausa skrupulatnie skopiowany. W dwudziestu czterech rozdziałach pierwszej księgi Ptolemeusz opisuje, krok po kroku, czynności, które należy wykonać, gdy przystępuje się do opracowywania map geograficznych; podaje rady i formułuje reguły oraz dodaje, w jaki sposób sam tego dokonał i jak robili to jego poprzednicy. Definiuje pojęcia geografii, kosmografii i chorografii, określa także zakresy tych dyscyplin.

W części rozpoczynającej się od słów: „QVIS cosmographiae finis: \& in quibus a corographia differat (...)" podaje, jakie zagadnienia naświetla chorografia, zgodnie z tradycją opisująca zamieszkały przez ludzi świat. Wspomina o sposobie doboru informacji oraz źródeł wiedzy geograficznej, które wykorzystał opracowując swoje dzieło. Ptolemeusz przywołał nie tylko wyniki obserwacji astronomicznych Hipparcha z Nikei (190-120 r. p.n.e.) czy Marinosa z Tyru (II w. n.e.), ale także relacje powtarzane za ateńskim historykiem Tukidydesem (V w. p.n.e.), który zebrał informacje $\mathrm{z}$ wielu wcześniejszych źródeł, prezentujących różne wersje opisu tych samych wydarzeń. Tak jak inni starożytni uczeni

\footnotetext{
${ }^{29} \mathrm{~K}$. Ajewski, Zbiory ikonograficzne Biblioteki Ordynacji Zamojskiej w Warszawie, „Rocznik Biblioteki Narodowej” 29, 1993, s. 35.

${ }^{30}$ Do tej pory nie zostały wykonane badania paleograficzne rękopisu.

${ }^{31} \mathrm{~W}$ literaturze przedmiotu i katalogach opisujących przywoływane powyżej kopie Geografii stosuje się ogólne stwierdzenie „kopia wykonana przez Nicolausa". Prac nie dzieli się na poszczególne etapy - przygotowanie kart pergaminowych, zapisanie tekstu, kopiowanie map, sporządzanie iluminacji. Jedyne, co jest podkreślane, to fakt, że ten niemiecki benedyktyn bez wątpienia był redaktorem map i samodzielnie opracowat je na podstawie danych geograficznych zapisanych w księgach II-VII.

32 „Cum quae summo ingenio exquisitaque doctrina Ptolemeus cosmographus pinxisse[t], in his aliquid novare attentaremus, fore ut hic noster labor in multorum reprehensiones incurreret. Omnes enim, qui hanc nostram picturam, quae his tabulis quas ad te misimus $\operatorname{co}[n]$ tinetur, viderint, geometrice praesertim rationis ignari, ab ea, quam Ptolemeus edidit, paululum abhorrentem, certe nos vel imperitiae vel temeritatis argument (...)" (k.1ra).
} 
Ptolemeusz zakładał, że istnieje obiektywna tendencja uściślania wiedzy poprzez uzupełnienie własnymi obserwacjami zasłyszanych lub zapisanych informacji, w celu przekazania ich kolejnym pokoleniom. Według Ptolemeusza miało to szczególne znaczenie $\mathrm{w}$ przypadku danych geograficznych. Na przykład dzieło wymienionego w Geografii Marinosa było dla niego jednym z bardziej wiarygodnych źródeł, szczególnie w przypadku, gdy informacje podawane były za Tukidydesem.

Komentującźródła Ptolemeusz wyjaśnił przyczyny różnic między wynikami otrzymanymi w rezultacie pomiarów terenowych i obserwacji astronomicznych. Pisał, że pomiary terenowe dostarczają względnych odległości w milach lub stadionach między obiektami na powierzchni Ziemi, zaś wyniki obserwacji astronomicznych pozycjonują obiekty poprzez mierzenie przypisanych im kątów. Starożytny geograf uważał, że zapisy spostrzeżeń podróżujących wzdłuż i wszerz świata ludzi są wiarygodne, a narysowanie na ich podstawie mapy świata - chociaż z pewnymi błędami - jest możliwe do wykonania, nawet jeśli początkowo dane wydają się nie budzić zaufania. Jako przykład źródła Ptolemeusz podał: „wyniki pomiarów kątowych szerokości geograficznej liczonych przez Hipparcha z Nikei na podstawie górowań gwiazdy polarnej dla niektórych miast spośród licznych wymienionych w Geografii, a także zaznaczył miejsca położone na tym samym równoleżniku [kąty długości geograficznej]. Jego zaś następcy te wyniki przeliczyli, stosując tradycyjne metody, i podali dla miejsc położonych przeciwstawnie (na północy i na południu), lecz nie dla tych równo oddalonych od równika, lecz po prostu położonych na tym samym południku"33.

„Bardzo liczne błędy odległości, zwłaszcza te, które liczono na kierunku wschodnim lub zachodnim pozostały z dawnych czasów: nie z niedbałości autorów, lecz dlatego, że nie było jeszcze zwyczaju starannej matematyki, prócz tego, że nieliczne niezwykłe fenomeny związane $\mathrm{z}$ księżycem $\mathrm{w}$ tym samym czasie $\mathrm{w}$ różnych miejscach były zaobserwowane. Na przykład zaćmienie owe, które w Arbilis było o godzinie piątej, w Kartaginie było odnotowane o go- dzinie drugiej. $\mathrm{Z}$ tego można wywnioskować, o ile godzin równonocnych [na tym samym równoleżniku], albo o ile odległości czasowych miejsca te są odległe między sobą w odniesieniu do wschodu słońca lub zachodu. Słusznie także opisano w Kosmografii, że jak najbardziej zgadzają się ze sobą miejsca, które zostały oznaczone dzięki starannym obserwacjom, i które są podane jako fundamentalne dzieła, z tymi, które zostały zaadaptowane na podstawie wcześniejszych obserwacji i przekazów tradycji”" ${ }^{34}$.

Powyższe, może nie dosłowne, ale pełne tłumaczenie objaśnień Ptolemeusza przybliża czytelnikowi sposób narracji, jaki stosuje Nicolaus. Ten odnotowany w starożytności fenomen identycznego położenia księżyca na ekliptyce w nocy 20 września 331 r. p.n.e. ${ }^{35}$ w dwóch oddalonych miejscowościach można oczywiście opisać prościej. Pierwsze wyniki obserwacji zapisane zostały o godzinie 2:00 w nocy w Kartaginie (obecnie 36 $51^{\prime} \mathrm{N}$, $\left.10^{\circ} 19^{\prime} \mathrm{E}\right)$, a drugie o 5:00 nad ranem w mieście Arbela (obecnie Erbil w Iraku 36 $10^{\circ} \mathrm{N}$, $44^{\circ} 01^{\prime}$ E). Według wyjaśnień Ptolemeusza, te trzy godziny odpowiadają ok. 45 stopniom różnicy w długości geograficznej (w rzeczywistości $33^{\circ} 41^{\prime}$ ) i określają odległość między miastami. Na marginesie można by dodać, że porównanie obecnych oznaczeń współrzędnych tych

\footnotetext{
${ }^{33}$ „Sed cum solus Hipparcus paucarum admodum civitatum pro earum copia quae in Cosmographia notantur elevationes poli arctici nobis tradiderit, ac loca per pauca sub eisdem sita paralellis notaverit. Aliqui vero post ipsum quaedam retulerint locorum oppositorum, non tamen quae aequaliter distarent ab aequatore, sed simpliciter sub eisdem sita meridianis" (k. 3vb).

${ }^{34}$ "Quamplures autem distantiarum, praesertim quae ad ortum solis sive ad occasum vergerent, conceptae fuerint ex generali quaedam traditione, non ex auctorum ipsorum ignavia, sed quod nondum diligentioris mathematicae usus foret praeterea quia non multi defectus lunares in eodem tempore diversis in locis tum observati fuerant. Quemadmodum eclipsis illa, quae in Arbilis sub hora quinta, in Carthagine vero sub secunda notata fuit, ex quibus videri posset quot horis aequinoctialibus, seu quot temporum spatiis, loca inter sese distarent ad ortum solis vel ad occasum, aequum quoque est descripturum Cosmographiam, quae noverit diligentiori observatione notata, tanquam operis sui fundamenta praeponere; alia autem a caeteris tradita his adaptare, quousque ipsorum invicem situs, quam maxime fieri possit, cum primis traditionibus certiores inveniantur" (k. 3vb)

${ }^{35}$ Jedenaście dni przed słynną w starożytności bitwą pod Gaugamela między wojskami Aleksandra Wielkiego i Dariusza III.
} 
dwu miejscowości przypomina o ptolemejskim błędzie polegającym na zbyt dużym, o ok. $20^{\circ}$ rozciągnięciu Morza Śródziemnego (z rzeczywistych $40^{\circ}$ do $60^{\circ}$ ) oraz ekumeny z ok. $130^{\circ}$ do $180^{\circ} \mathrm{w}$ stosunku do $360^{\circ}$ długości kątowej całej kuli ziemskiej ${ }^{36}$.

Podsumowaniem pierwszej księgi jest wyjaśnienie zasad konstrukcji dwu tzw. ptolemejskich odwzorowań kartograficznych (stożkowych): pierwszego, pomocnego przy rysowaniu map regionalnych oraz drugiego, znanego ówczesnej kulturze basenu Morza Śródziemnego, służącego do zredagowania mapy całe-
Księgi II-VII w zapisie Nicolausa Germanusa zawierają podzielone na 91 rozdziałów opisy geograficzne poszczególnych regionów, a w księdze VIII znajdują się dwa rozdziały podsumowujące opisanie świata. W księdze II zamieszczono opisy Europy, poczynając od północno-zachodnich jej krańców - od Irlandii (k. 13vb), kończąc na sięgającej na wschodzie po Wisłę Germanii. Opisy księgi III zawierają informacje geograficzne dotyczące Europy wschodniej i południowo-wschodniej - od Półwyspu Apenińskiego (k. 24vb), poprzez Sarmację po Grecję. Księga IV zawiera dane

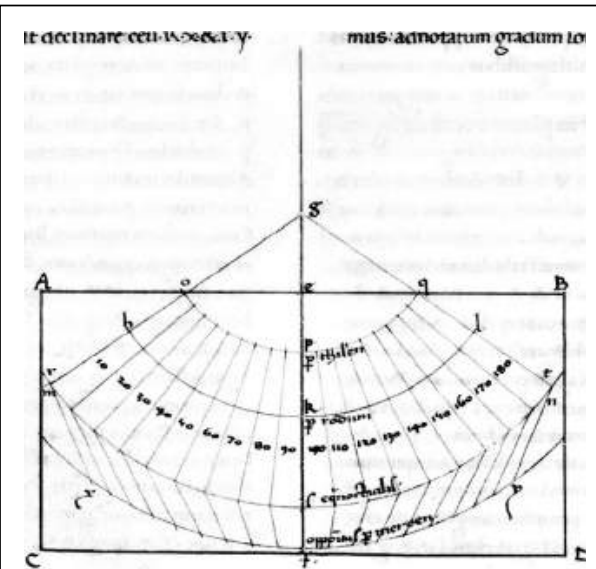

(a)

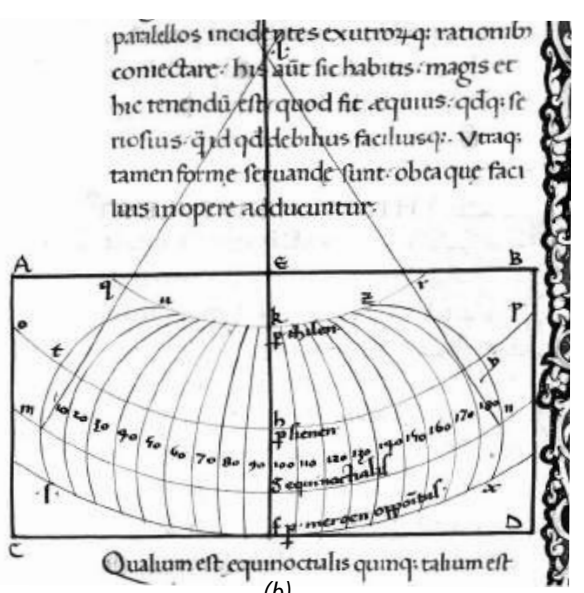

(b)

Ryc. 2. Ptolemejskie odwzorowania stożkowe: tzw. pierwsze (a) oraz drugie (b)

go świata. Obie konstrukcje kartograficzne umożliwiają przenoszenie danych oznaczonych współrzędnymi geograficznymi ze sfery kulistej na powierzchnię płaską (ryc. 2).

Konstrukcja i rysowanie siatki południków i równoleżników zostało objaśnione krok po kroku z wykorzystaniem zasad zaczerpniętych z geometrii Euklidesa. Gdy pod koniec średniowiecza odkryto tekst Geografii, właśnie te wyjaśnienia pozwoliły późniejszym twórcom map na stosowanie podstawowych zasad konstrukcji odwzorowań kartograficznych. Przedstawieniem drugiego odwzorowania kończy się księga pierwsza, o czym informuje następujący po nim napis: „CLADII [!] PTOLOMEI COSMOGRAPHIE LIBER PRIMVS EXPLICIT”. dotyczące Afryki, z których zaczerpnięto informacje do czterech map. Rozpoczyna ją opis Mauretanii (k. 36va), sięgającej na zachodzie Słupów Herkulesa, a kończy opis Egiptu. Po nim następuje opis regionów Afryki położonych na południe od posiadłości rzymskich, na podstawie którego narysowano czwartą, nietypową mapę Afryki obejmującą swym zasięgiem znane w starożytności wnętrze kontynentu aż po Góry Księżycowe na południe od równika. Księgę V rozpoczyna opisanie Azji od krainy Pontu (k. 41ra), poprzez Sarmację Azjatycką oraz kraje Bliskiego Wschodu wraz z Półwy-

\footnotetext{
${ }^{36}$ L. Szaniawska, „Geografia” Ptolemeusza prekursorskim zbiorem danych przestrzennych, s. 131-132.
} 
spem Arabskim, kończąc na Babilonii. Księga VI omawia kraje Azji Centralnej od Asyrii (k. 55ra), poprzez krainy Zakaukazia, po Persję i krainy będące pod jej dominacją. W księdze VII zawarto informacje o Azji południowowschodniej i wschodniej, od Indii (k. 62va), po Chiny i Wyspy Indonezyjskie oraz wyspę Taprobana (koniec opisu k. 67va). Księgę VII kończy Epilogus (k. 69rb-69va).

Budowa opisów wszystkich regionów opiera się na wspólnym schemacie. Całość rozpoczyna się od opisania granic i podania nazw krajów graniczących z danym regionem. Dalej następują omówienia obiektów geograficznych ułożone według prowincji lub większych jednostek politycznych bądź administracyjnych, wewnątrz których się znajdują. Po nazwie prowincji wymieniane są zwykle rzeki wraz ze współrzędnymi geograficznymi ich ujść i źródeł. Współrzędne podano zawsze w następującym układzie: pierwsze dane dotyczą długości geograficznej $(\lambda)$ liczonej na wschód od Ferro, wyspy wchodzącej w skład Wysp Kanaryjskich ${ }^{37}$, drugie - szerokości $(\varphi)$ liczonej od równika (na północ bez podania kierunku oraz na południe $\mathrm{z}$ dodaną o tym informacją, np. „Barditi montis medium $45^{\circ} \lambda$ ” $i$,australis $\left.16^{\circ} \varphi^{\prime}\right)$. Po rzekach wymieniane są góry, po nich - nazwy plemion, a jako ostatnie - miasta. Taką kolejność danych zastosowano między innymi w regionie zwanym „LIBYA”. Jeżeli w regionie znalazło się mniej toponimów, nie dzielono ich na rodzaje, tylko w każdej prowincji wyliczano je łącznie, np. dla Korsyki toponimy wymieniono w ramach wydzielonych części, nazwanych w następujący sposób: „Occidentalis lateris descriptio”, "Meridionalis lateris descriptio”, „Orientalis lateris descriptio”, „Reliqua septentrionalis lateris”, „Tenent autem insulam, populi Villas (...)” oraz „Ciuitates mediterraneae hec sunt”. Dla Sardynii nazwy wydzieleń są podobne, ale całość kończy wyliczenie okolicznych wysp zatytułowane INSVLAE circa sardiniam sunt. Dane geograficzne do mapy SEXTA asyae tabula continet arabiam felicem atquae carmaniam... (Półwyspu Arabskiego i Karmanii) zostały podzielone na regiony i królestwa, których granice naniesiono na mapę liniami kropkowanymi.
W podobny sposób, dzieląc dane na dystrykty, których granice naniesiono na mapy, ułożono toponimy Hiszpanii, Galii i innych regionów Europy (Italię podzielono na regio). Jeżeli w regionie znalazło się mniej toponimów, nie dzielono ich na rodzaje, tylko w każdej prowincji wyliczano je bez wydzieleń.

Omówienie regionów w księdze VII Geografi Ptolemeusza kończy rozdział opisujący Cejlon TAPRABANES INSVLE SITVS. Po nim następują jeszcze trzy rozdziały. W Summaria descriptio tabule nostri orbis (k. 67vb-68v) jest podsumowana całość geograficznego opisania ekumeny. Kolejny - Circularis sphere cum habitabili terra descriptio (k. 68v) ponownie objaśnia konstruowanie siatki kartograficznej z przecinających się południków i równoleżników, przechodzących przez oznaczone i nazwane punkty takie jak Rodos, Thule, Alexandria. Po rozdziale Epilogus prefate extensionis na k. 69r, na odwrocie karty rozpoczyna się księga VIII CLAVDII PTOLOMEI COSMOGRAPHIE LIBER OCTAVVS HEC HABET Cum qua presupositione facere oporteat habitabilis nostri orbis diuisionem ad tabulas. Księga ta została prawdopodobnie zredagowana przez Nicolausa i jest zapowiedzią następującego po niej zbioru map całego zamieszkałego świata, który rozpoczyna mapa świata Tabula nostri orbis. Sumuje ona informacje o regionach, zawarte na mapach ptolemejskich: dziesięciu - Europy, czterech Afryki i dwunastu - Azji (,aggredientes Europae Tabulas decem constituemus. Africae Tabulas quattuor. Totius Asiae Tabulas duodecim" k. 70rb).

\section{Treść map Geografii redagowanych przez Nicolausa Germanusa w BOZ 2}

Mapy stanowią drugą, odrębną fizycznie część traktatu. Zapewne już podczas oryginalnego, przeprowadzonego we Florencji oprawiania tekstu i map traktatu ${ }^{38}$ introligator przycią marginesy kodeksu (szczególnie górny mar-

\footnotetext{
${ }^{37}$ Południk Ferro oddalony jest na zachód od Greenwich $017^{\circ} 40^{\prime} \lambda$.

${ }^{38}$ Takie przypuszczenie sugeruje analogiczne przycięcie kart $w$ dwóch kopiach kodeksu przechowywanych we Florencji (Plut. 30.03 oraz Plut. 30.04).
} 
gines o ponad $4 \mathrm{~cm}$ ), przez co bezpowrotnie zubożył zdobiącą dzieło floraturę. Ponowne oprawienie traktatu, i być może podzielenie go na dwa woluminy, miało miejsce w XIX wieku. Po konserwacji wykonanej w 2005 roku, mapy tworzą zbiór 30 prezentacji kartograficznych (tab. 1) - każda na osobnym arkuszu pergaminu. W oryginalnej formie woluminu zbiór nie posiadał odrębnej informacji o zawartości. Obecnie karty z mapami nie zostały złożone na pół i są nieoprawione, co między innymi zapobiega dalszemu niszczeniu warstwy malar-

Tabela 1. Wykaz dawnych map Ptolemeusza i „tabulae modernae” Nicolausa w rękopisie B0Z 2, w oryginalnej kolejności39 z oryginalnymi nazwami regionów oraz z ich objaśnieniami

\begin{tabular}{|c|c|c|}
\hline 1. & Tabula nostri orbis & Mapa naszego globu \\
\hline 2. & PRIMA europe tabula insulas britannicas continet... & Mapa Wysp Brytyjskich \\
\hline 3. & SECVNDA europe tabula continet hispaniam totam... & Mapa Półwyspu Pirenejskiego \\
\hline 4. & Tabula moderna Hispaniae & Nowa mapa Hiszpanii \\
\hline 5. & TERTIA europe tabula continet galliam... & Mapa Galii \\
\hline 6. & QVARTA europe tabula continet germaniam cum insulis & Mapa Germanii \\
\hline 7. & Tabula Europae Septentrionalis & Nowa mapa Europy Północnej \\
\hline 8. & $\begin{array}{l}\text { QVINTA europe tabula continet rhetiam \& uindelicos ac Noricum duasque pannonias ac totam illiridem cum } \\
\text { adiacentibus insulis }\end{array}$ & Mapa krain nad Adriatykiem \\
\hline 9. & SEXTA europe tabula Italiam continet \& cyrnum insulam... & Mapa Półwyspu Apenińskiego \\
\hline 10. & Tabula moderna Italiae & Nowa mapa Italii \\
\hline 11. & SEPTIMA europe tabula continet Sardiniam \& Siciliam insula & Mapa Sardynii i Sycylii \\
\hline 12. & OCTAVA tabula continet Sarmatiam que in ea est \& Tauricam chersonesum & Mapa Sarmacji Europejskiej \\
\hline 13. & NONA europe tabula continet iaziges methanastas: Datiam utranque mysiam: Traciam et chersonesum & Mapa północnych Bałkanów \\
\hline 14. & $\begin{array}{l}\text { DECIMA europe tabula continet macedoniam \& epirum \& achaiam \& peloponesum \& cretam insulam } \\
\& \text { euboeam... }\end{array}$ & Mapa Grecji \\
\hline 15. & PRIMA lybiae tabula continet ambas mauritanias, tingintanam \& cesariensem & Mapa Afryki Północno-Zachodniej \\
\hline 16. & SECVNDA africae tabula continet africam \& insulas que circa ipsam sunt & Mapa prowincji Afryki Prokonsularnej \\
\hline 17. & TERTIA africe tabula continet cyrenaicam et egyptum... & Mapa prowincji Cyrenajki i Egiptu \\
\hline 18. & QVARTA \& ultima africe tabula continet interiorem lybiam \& aethiopiam que sub egipto est... & Mapa Afryki \\
\hline 19. & $\begin{array}{l}\text { PRIMA asiae tabula continet pontum \& bythiniam \& regionem que proprie asia dicitur ac lyciam \& gallatiam } \\
\text { ac pamphiliam \& cappadociam \& armeniam minorem \& ciliciam }\end{array}$ & Mapa Anatolii \\
\hline 20. & SECVNDA asiae tabula continet Sarmatiam ipsius & Mapa Sarmacji Azjatyckiej \\
\hline 21. & TERTIA asiae tabula continet colchidem, hiberiam, albaniam \& maiorem armeniam & Mapa Zakaukazia \\
\hline 22. & $\begin{array}{l}\text { QVARTA asyae tabula continet cyprum \& syriam \& iudeam \& utramque arabiam petream \& desertam ac } \\
\text { mesopotamiam \& babyloniam }\end{array}$ & Mapa Bliskiego Wschodu \\
\hline 23. & $\begin{array}{l}\text { QVINTA asiae tabula continet assyriam, susianam, medos, persidem, hyrcaniam, parthiam \& carmaniam } \\
\text { desertam }\end{array}$ & Mapa Imperium Partyjskiego \\
\hline 24. & SEXTA asyae tabula continet arabiam felicem atque carmaniam... & Mapa Półwyspu Arabskiego i Karmanii \\
\hline 25. & $\begin{array}{l}\text { SEPTIMA asyae tabula continet margianam, bactrianam, sogdianos, sacas \& scythiam intra Imaum } \\
\text { montem }\end{array}$ & Mapa zachodniej Scytii \\
\hline 26. & OCTAVA asiae tabula continet scythiam que circa Imaum est \& seras & Mapa wschodniej Scytii i Seriki \\
\hline 27. & NONA asiae tabula continet ariam \& paropanisadas \& drangianam \& arochosiam \& gedrosiam & Mapa Państwa Kuszanów \\
\hline 28. & DECIMA asiae tabula continet indiam intra gangem fluuium... & Mapa Indii \\
\hline 29. & VNdecima asyae tabula continet indiam extra gangem \& sinas & Mapa Azji na wschód od Gangesu \\
\hline 30. & DVODECIMA \& ultima Asiae tabula continet taprobanem insulam... & Mapa Cejlonu \\
\hline
\end{tabular}

\footnotetext{
${ }^{39}$ Oryginalnie numeracja kart jest zapisana liczbami rzymskimi, ale w wykazie map w artykule zastosowano liczby arabskie, by odróżnić je od użytych przez renesansowych redaktorów numeracji map np. przez S. Münstera TABVLA EVROPAE IIII GERMANIA MAGNA.
} 
skiej poprzez jej wykruszanie i odpryskiwanie w miejscach dawnego złożenia.

Po starym układzie map w kodeksie pozostała numeracja tablic zapisana liczbami rzymskimi na verso map w prawym górnym rogu ${ }^{40}$. Mapy o numerach kart IV (Tabula moderna Hispania $^{41}$, VII (Tabula Europae Septentrionalis) oraz X (Tabula moderna Italiae) to tzw. tabulae modernae, które Nicolaus narysował na podstawie najnowszych danych geograficznych znanych renesansowym twórcom map. Mapy północnych obszarów Europy i świata stanowią wyraźny przełom, wprowadzając dane o obiektach znajdujących się na północ od równoleżnika przechodzącego przez wyspę Thule $\left(63^{\circ} \varphi\right)$.
II-VII, stanowi zbiór, który w zamiarze Ptolemeusza miał pokazywać wszystkie znane oraz nieznane, ale wspominane przez starożytnych pisarzy, ziemie. Ptolemeusz zaplanował, że każda z map będzie prezentować jeden region. Część regionów była łatwa do nazwania i nie wzbudza wątpliwości, np. Galia, Germania, Egipt. Trudniej było z mapami, na których wspólnie zgrupowano mniejsze państwa czy krainy. Nie tylko Nicolaus miał kłopot z nazwaniem takich map - również obecnie trzeba użyć kilku nazw złożonych. Na przykład mapa 8 (QVINTA europae tabula), prezentująca siedem rzymskich prowincji i krain, od Recji po Illiricum, otrzymała na potrzeby tej publikacji tytuł Krainy nad

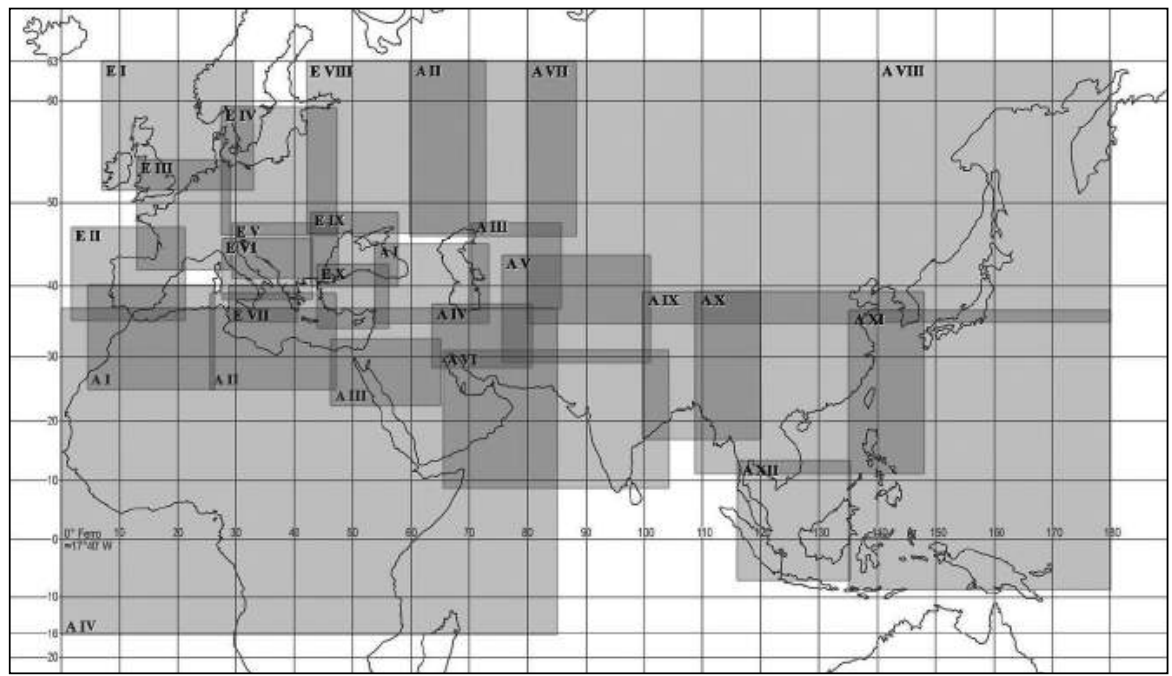

Ryc. 3. Zasięg dwudziestu sześciu map regionalnych Ptolemeusza w redakcji Nicolausa, zgodny z zapisami na ramkach map oraz zarysy kontynentów według aktualnego stanu wiedzy, oprac. J. A. Szaniawski

Na terenach sięgających na mapie Tabula nostri orbis do $65^{\circ} \varphi$ dołączono Grenlandię, tutaj narysowaną jako wąski i długi półwysep u swej nasady łączący się z Gothią. Natomiast ziemie opisane i narysowane na mapie Tabula Europae Septentrionalis są wysunięte jeszcze dalej na północ, aż do $72^{\circ} \varphi$, łącząc się z krainą „PILLAPELANTH”. Na północ od niej kończy się zamieszkana ziemia.

Dwadzieścia sześć map regionalnych (chorograficznych), redagowanych na podstawie danych geograficznych zawartych w księgach
Morzem Adriatyckim. Konieczność łączenia małych krain na jednej mapie wynikała $\mathrm{z}$ dysponowania jednakowej wielkości kartami pergaminu użytymi do ich namalowania. Ramki mapy, utworzone z linii prostych, z oczywistych powodów tną krainy geograficzne na dosyć przypadkowe części. Zaistniała zatem konieczność wypełniania pustych powierzchni pergaminu

\footnotetext{
${ }^{40}$ Obrazy map wraz z ich verso prezentowane są w bazie CBN Polona (dostęp: http://www.polona.pl, 17 marca 2012).

${ }^{41} \mathrm{~W}$ tab. 1, nr 4.
} 
wokół regionów uproszczoną treścią, dotyczącą okolicznych terenów. Z drugiej strony liczba danych geograficznych odnoszących się mniej znanych, odległych krain, ustępowała wiedzy o imperium rzymskim. I w ten sposób powstały mapy obejmujące obszary o powierzchniach znacznie różniących się między sobą (ryc. 3).

Dla lepszego zorientowania czytelnika w położeniu danego regionu dobrym zwyczajem twórców map było umieszczanie nazw krain z map przylegających do siebie oraz fragmentów ich obszarów. Konsekwencją takiego zabiegu było powtarzanie także obrazu przylegających do siebie krain. Takie reguły, znane w renesansie, zostały zastosowane przez redaktora, chociaż nie ustrzegł się on przy tym pewnych błędów. Na północy mapa 19 (PRIMA asiae ta- bula - Mapa Anatolii) sięga do $45^{\circ} \varphi$, zaś mapa 20 (SECVNDA asiae tabula - Mapa Sarmacji Azjatyckiej), która powinna kontynuować jej treść, rozpoczyna się przy dolnej ramce dopiero od $46^{\circ} \varphi$, co powoduje, że obszar o szerokości jednego stopnia mierzonego po południku i długości prawie dwudziestu stopni (a więc szerokości około 94,4 km i długości prawie 1900 $\mathrm{km}$ ), mierzonych wzdłuż równoleżnika, nie jest naniesiony na żadną z tych map (ryc. 3). Również stopień zachodzenia na siebie obrazu prezentowanego na sąsiednich arkuszach nie jest jednakowy. Czasami wspólny pas jest tylko jedno- lub kilkustopniowy, jak w przypadku mapy 3 (SECVNDA europe tabula - Półwyspu Pirenejskiego) i mapy 15 (PRIMA lybiae tabula - Afryki północno-zachodniej), gdzie wyno-

Tabela 2. Wykaz map Ptolemeusza w redakcji Nicolausa Germanusa wraz z ich oznaczeniami w ryc. 3 obliczonymi skalami i zasięgami (zapisanymi stopniami geograficznymi na ramkach map)

\begin{tabular}{|c|c|c|c|c|c|c|}
\hline \multirow{3}{*}{ Nazwa mapy } & & \multirow{3}{*}{ Skala mapy } & \multicolumn{4}{|c|}{ Ramki } \\
\hline & & & lewa & prawa & górna & dolna \\
\hline & & & \multicolumn{2}{|c|}{$\lambda$ E liczone od Ferro } & \multicolumn{2}{|c|}{$\varphi$ liczone od równika } \\
\hline Tabula nostri orbis & & $1: 38000000$ & & & & \\
\hline PRIMA europe tabula & EI & $1: 3300000$ & $7^{\circ}$ & $33^{\circ}$ & $63^{\circ} \mathrm{N}$ & $51^{\circ} 30^{\prime} \mathrm{N}$ \\
\hline SECVNDA europe tabula & E II & $1: 3000000$ & $2^{\circ}$ & $21^{\circ}$ & $47^{\circ} \mathrm{N}$ & $35^{\circ} 20^{\prime} \mathrm{N}$ \\
\hline TERTIA europe tabula & $E I I I$ & $1: 3600000$ & $13^{\circ}$ & $29^{\circ}$ & $54^{\circ}$ & $42^{\circ} \mathrm{N}$ \\
\hline QVARTA europe tabula & EIV & $1: 3700000$ & $27^{\circ}$ & $47^{\circ}$ & $59^{\circ} 30^{\prime} \mathrm{N}$ & $46^{\circ} \mathrm{N}$ \\
\hline QVINTA europe tabula & EV & $1: 2900000$ & $29^{\circ} 30^{\prime}$ & $47^{\circ}$ & $47^{\circ} 30^{\prime} \mathrm{N}$ & $41^{\circ} \mathrm{N}$ \\
\hline SEXTA europe tabula & $\mathrm{EVI}$ & $1: 2200000$ & $28^{\circ}$ & $43^{\circ}$ & $45^{\circ} 30^{\prime} \mathrm{N}$ & $38^{\circ} \mathrm{N}$ \\
\hline SEPTIMA europe tabula & E VII & $1: 1600000$ & $29^{\circ}$ & $40^{\circ} 15^{\prime}$ & $40^{\circ} \mathrm{N}$ & $35^{\circ} \mathrm{N}$ \\
\hline OCTAVA tabula continet Sarmatiam & E VIII & $1: 4500000$ & $42^{\circ}$ & $72^{\circ} 30^{\prime}$ & $63^{\circ} \mathrm{N}$ & $46^{\circ} 30^{\prime} \mathrm{N}$ \\
\hline NONA europe tabula & EIX & $1: 2600000$ & $42^{\circ} 30^{\prime}$ & $58^{\circ}$ & $48^{\circ} 30^{\prime} \mathrm{N}$ & $40^{\circ} \mathrm{N}$ \\
\hline DECIMA europe tabula & $E X$ & $1: 2400000$ & $44^{\circ}$ & $56^{\circ}$ & $42^{\circ} 30^{\prime} \mathrm{N}$ & $34^{\circ} \mathrm{N}$ \\
\hline PRIMA lybiae tabula & $\mathrm{Al}$ & $1: 4800000$ & $4^{\circ} 30^{\prime}$ & $26^{\circ} 30^{\prime}$ & $40^{\circ} \mathrm{N}$ & $25^{\circ} \mathrm{N}$ \\
\hline SECVNDA africae tabula & All & $1: 4200000$ & $26^{\circ}$ & $47^{\circ}$ & $39^{\circ} \mathrm{N}$ & $25^{\circ} \mathrm{N}$ \\
\hline TERTIA africe tabula & A III & $1: 3800000$ & $46^{\circ} 30^{\prime}$ & $65^{\circ}$ & $32^{\circ} 30^{\prime} \mathrm{N}$ & $22^{\circ} 30^{\prime} \mathrm{N}$ \\
\hline QVARTA \& ultima africe tabula & AIV & $1: 18000000$ & $0^{\circ}$ & $85^{\circ}$ & $37^{\circ} \mathrm{N}$ & $16^{\circ} \mathrm{S}$ \\
\hline PRIMA asiae tabula & $\mathrm{Al}$ & $1: 3200000$ & $54^{\circ}$ & $73^{\circ}$ & $45^{\circ} \mathrm{N}$ & $35^{\circ} \mathrm{N}$ \\
\hline SECVNDA asiae tabula & A\|I & $1: 4500000$ & $60^{\circ}$ & $88^{\circ}$ & $63^{\circ} \mathrm{N}$ & $46^{\circ} \mathrm{N}$ \\
\hline TERTIA asiae tabula & A III & $1: 2700000$ & $70^{\circ} 30^{\prime}$ & $86^{\circ}$ & $47^{\circ} 30^{\prime} \mathrm{N}$ & $38^{\circ} \mathrm{N}$ \\
\hline QVARTA asyae tabula & AIV & $1: 2900000$ & $63^{\circ} 30^{\prime}$ & $80^{\circ} 30^{\prime}$ & $38^{\circ} 30^{\prime} \mathrm{N}$ & $28^{\circ} \mathrm{N}$ \\
\hline QVINTA asiae tabula & $\mathrm{AV}$ & $1: 4300000$ & $75^{\circ} 30^{\prime}$ & $101^{\circ}$ & $43^{\circ} 30^{\prime} \mathrm{N}$ & $29^{\circ} \mathrm{N}$ \\
\hline SEXTA asyae tabula & $\mathrm{AVI}$ & $1: 8300000$ & $66^{\circ}$ & $104^{\circ}$ & $31^{\circ} \mathrm{N}$ & $9^{\circ} 15^{\prime} \mathrm{N}$ \\
\hline SEPTIMA asyae tabula & A VII & $1: 10000000$ & $80^{\circ}$ & $140^{\circ}$ & $63^{\circ} \mathrm{N}$ & $35^{\circ} \mathrm{N}$ \\
\hline OCTAVA asiae tabula & A VIII & $1: 7700000$ & $140^{\circ}$ & $180^{\circ}$ & $63^{\circ} \mathrm{N}$ & $35^{\circ} \mathrm{N}$ \\
\hline NONA asiae tabula & AIX & $1: 5900000$ & $100^{\circ}$ & $120^{\circ}$ & $39^{\circ} \mathrm{N}$ & $17^{\circ} \mathrm{N}$ \\
\hline DECIMA asiae tabula & $\mathrm{AX}$ & 1:8700000 & $109^{\circ}$ & $148^{\circ} 30^{\prime}$ & $39^{\circ} \mathrm{N}$ & $11^{\circ} \mathrm{N}$ \\
\hline VNdecima asyae tabula & $\mathrm{AXI}$ & $1: 14300000$ & $135^{\circ}$ & $180^{\circ}$ & $37^{\circ} \mathrm{N}$ & $9^{\circ} \mathrm{S}$ \\
\hline DVODECIMA \& ultima Asiae tabula & AXII & $1: 8300000$ & $116^{\circ}$ & $135^{\circ}$ & $13^{\circ} \mathrm{N}$ & $7^{\circ} \mathrm{S}$ \\
\hline
\end{tabular}


si około pięciu stopni. W Azji bywa znacznie większy, jak na mapach 27 (NONA asiae tabula - Mapa Państwa Kuszanów) oraz 29 (VNdecima asyae tabula - Mapa Azji na wschód od Gangesu), gdzie sięga aż trzynastu stopni.

Konsekwencją różnych zasięgów map było także zastosowanie różnych stopni pomniejszenia obrazowanego terenu. W stosunkowo zbliżonej do siebie skali pokazano terytorium imperium rzymskiego oraz pozostałej części Europy, zaś obszary odległe, szczególnie położone we wschodniej Azji, pomniejszono trzykrotnie (ryc. 3 oraz tab. 2). Mapę zbiorczą Afryki 18 (QVARTA \& ultima africe tabula), ukazująca także tereny na południe od równika, przedstawiono w skali prawie czterokrotnie mniejszej niż pozostałe trzy mapy regionów Afryki (tab. 2). Mapę całego znanego świata obejmującą obszary od Wysp Kanaryjskich na zachodzie po wyspy południowo-wschodniej Azji oraz na północy od Grenlandii zaś na południu po afrykańskie Góry Księżycowe narysowano w skali dziesięciokrotnie mniejszej niż mapy imperium rzymskiego (tab. 2).

Zarówno te, jak i wiele innych niekonsekwencji redaktora przedstawiają także zestawione $\mathrm{w}$ tab. 2 północne i południowe zasięgi wszystkich regionalnych map Ptolemeusza. Na ryc. 3 zilustrowano wzajemne położenie arkuszy. Rycina ta pokazuje także, jaki fragment Ziemi powinien znaleźć swoją prezentację, jeżeli dane geograficzne Ptolemeusza byłyby zgodne $\mathrm{z}$ rzeczywistymi. Widoczny jest też na niej znany „błąd Ptolemeusza”, polegający na nieprecyzyjnych obliczeniach położenia obiektów geograficznych, kumulujący się wraz z posuwaniem się na wschód. I tak współrzędne geograficzne obiektów, które znalazły się na mapie 28 (DECIMA asiae tabula; na ryc. 3 oznaczona A X), obrazującej głównie Półwysep Indyjski, są oznaczone wartościami położenia tak dużymi, że powinny znaleźć się na mapie 29 (VNdecima asyae tabula; na ryc. 3 oznaczona A XI), czyli w Indiach Zagangeskich (w Azji południowo-wschodniej). Na przykład ujście Gangesu na mapie Nicolausa usytuowane jest na około $150^{\circ} \lambda$ od Ferro, a w rzeczywistości leży na około $107^{\circ} \lambda$ od Ferro. W tym przypad- ku błąd położenia wynosi aż $43^{\circ}$. Zaś na mapie 29 (VNdecima asyae tabula), o współrzędnych zasięgu mierzonego wzdłuż równoleżnika od $135^{\circ} \lambda$ do $180^{\circ} \lambda$, powinny być przedstawione Nowa Gwinea, archipelag Filipin i Mikronezja.

W tym miejscu należy zwrócić uwagę na jeszcze jedną nieporadność Nicolausa ${ }^{42}$. Treść mapy rysowana na przystających do siebie arkuszach, jak już wyżej nadmieniono, częściowo pokrywa się lub kontynuuje, ale na zewnętrznych brzegach arkuszy „urywa się" na $180^{\circ} \lambda$ i dalej na wschód brak kontynuacji obrazu Ziemi. Odbiorca zapewne zinterpretuje to tak, że kartograf nie wiedział, co dalej się znajduje. $\mathrm{Na}$ wcześniejszych średniowiecznych mapach, tzw. mappae mundi, wszystkie lądy były otoczone wodami „wszechoceanu” i takie przedstawienie było pewnym zamkniętym obrazem lądów Ziemi. Na mapach Ptolemeusza na obszarze północno-wschodniej i wschodniej Azji, gdzie rzeki i góry dochodzą do ramki mapy, nie oznaczono, co znajduje się dalej. W podobnej sytuacji na obszarach północnej Europy i południowej Afryki dodano informację terra incognita. Jest to rozwiązanie, może nie w pełni satysfakcjonujące, ale za to merytorycznie poprawne. Dlaczego nie postąpiono tak w przypadku wschodnich kresów Regio Serica i Sina Regio? Ten brak konsekwencji zauważył także niderlandzki kartograf i wydawca Gerard Mercator i na mapie ASIAE XI TAB wydanej po raz pierwszy w 1578 r. (ryc. 4) na obszarze wschodnich krańców Chin dodał wyjaśnienie mówiące, że „pozostała część kontynentu, w kierunku wschodnim i południowym, nie była znana Ptolemeuszowi, sądził on jednak, że $\mathrm{z}$ tego miejsca ziemie ciągną się na południe i zachód, wraz z przylądkami Prassum i Rhaptum i południową częścią Azanii, która znajduje się we wschodniej części Afryki”.

$\mathrm{Na}$ tle wcześniejszych i współczesnych $\mathrm{Ni}$ colausowi Germanusowi prezentacji znanego wówczas świata, jego prezentacja danych geograficznych Ptolemeusza była, pomimo pewnych uchybień, znacznie lepsza. Trzeba przyznać, że

\footnotetext{
${ }^{42}$ Na korzyść Nicolausa przemawia fakt, że w podobny sposób postępowali i inni twórcy map.
} 


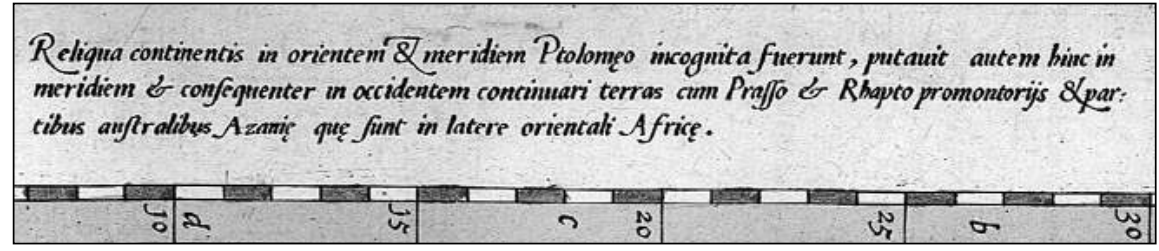

Ryc. 4. Tekst Mercatora na mapie ASIAE XI TAB (w atlasie wydanym w roku 1584), umieszczony na obszarze wschodnich peryferii Azji, Warszawa, IH UW"3

Nicolaus był sumiennym interpretatorem zapisów danych aleksandryjskiego uczonego i co więcej, wzbudził zaufanie współczesnych mu odbiorców. $\mathrm{Na}$ podstawie jego rękopiśmiennych map ukazywały się pierwsze drukowane wersje Geografii. Późniejsze redakcje różniły się często jedynie mało istotnymi szczegółami albo wręcz były mniej udane. Jednakże jedno z opracowań, autorstwa Gerarda Mercatora, który ponownie poddał redakcji mapy Ptolemeusza, zasługuje na wyjątkowe zainteresowanie ba- daczy. Nie włączył on do zredagowanej przez siebie Geografii żadnych tabulae modernae, lecz skupił się na precyzyjnym odtworzeniu obrazowania danych Ptolemeusza. Oczywiście jego mapy musiały różnić się od prezentacji kartograficznych działającego o ponad wiek wcześniej we Florencji benedyktyna. Sposoby rysowania i kopiowania map zostały znacznie unowocześnione. Najważniejszą zmianą, którą wprowadził Mercator było otwarcie na południu Oceanu Indyjskiego. Zobrazowane na

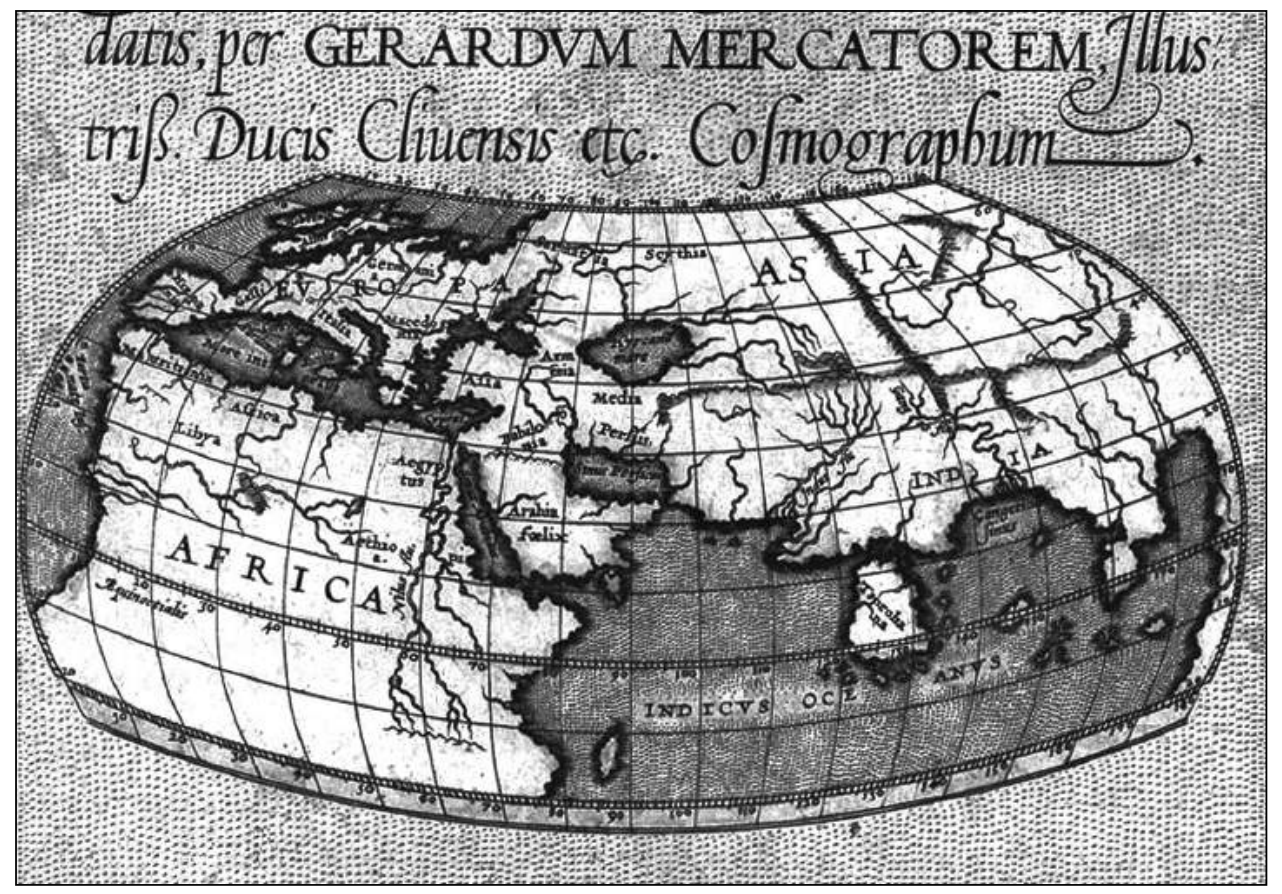

Ryc. 5. Mapa ekumeny Ptolemeusza według Gerarda Mercatora na karcie tytułowej edycji „Geografii” z 1584 roku, Warszawa, IH UW

\footnotetext{
${ }^{43}$ Warszawa, Instytut Historyczny Uniwersytetu Warszawskiego, [dalej: Warszawa, IH UW]. Wydanie atlasu z 1584 roku.
} 
mapie przez Nicolausa „MARE INDICVM” stało się merkatorowskim oceanem „INDICVS OCEANVS" (ryc. 5), co oczywiście stanowiło konsekwencję osiągnięć epoki Wielkich Odkryć Geograficznych.

Nicolaus, jako pierwszy z redaktorów, każdej mapie regionalnej odwzorowanej w rzucie stożkowym nadał formę trapezu ${ }^{44}$, a nie - jak jego poprzednicy - formę prostokąta. Jego zdaniem, proporcje boków i kątów trapezu lepiej symalnej długości dnia w godzinach i ich częściach oraz odległością godzinową od Aleksandriii ${ }^{47}$. Miary te nawiązują do miar zapisanych na marginesach map, nie występują natomiast w tekście Ptolemeusza. Oznaczenie wybranych równoleżników na marginesie każdej mapy zostało wzbogacone współrzędnymi geograficznymi zapisanymi na ramce (ryc. 6), nawiązującymi do oznaczeń położenia zapisanych przez Ptolemeusza w księgach od II do VII.
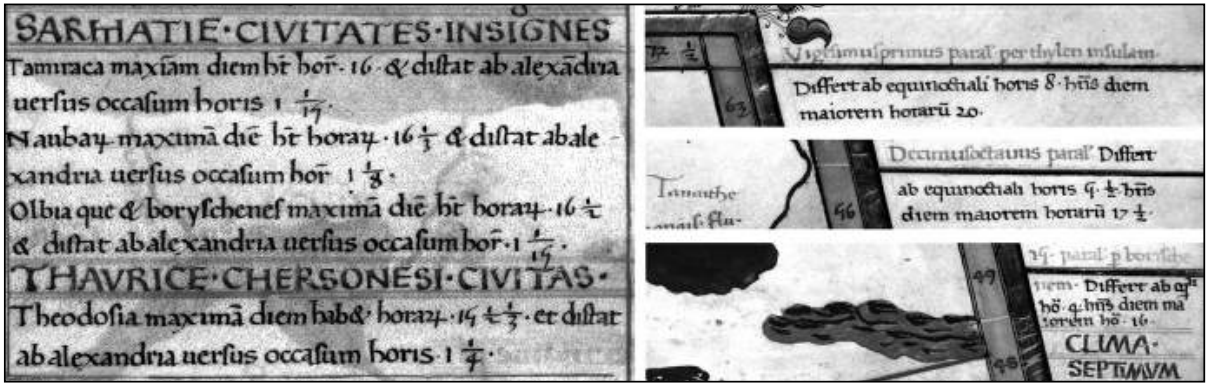

Ryc. 6. Oznaczenie położenia geograficznego określone przez Nicolausa maksymalną długością dnia w roku oraz odległością godzinową od Aleksandrii na przykładzie mapy Sarmacji Europejskiej

odwzorowują oczka siatki geograficznej i wierniej oddają rzeczywiste odległości ${ }^{45}$. Na mapie Prima europe tabula - Irlandii i Wysp Brytyjskich Nicolaus uzasadnia swój wybór sposobu prezentacji następująco: różnica długości między częścią górną i dolną mapy wynosi 2340 stadionów, czyli 250 mil. Należało tak uczynić dla wygody oraz dokładności graficznego prze$\mathrm{kazu}^{46}$. Nie tylko na różnych szerokościach geograficznych mapy mają odmienne wymiary, ale także boki trapezu są mniej nachylone na mapach prezentujących obszary położone bliżej równika, a bardziej nachylone na większych szerokościach, jak np. Wysp Brytyjskich czy Sarmacji Azjatyckiej.

Do tej zmienności rozmiarów map przyczyniają się wielkości prezentowanych przez nie terenów. Zapewne dlatego każda z dwudziestu sześciu regionalnych map Ptolemeusza poprzedzona jest jednostronicowym geograficznym wstępem mówiącym o zasięgu mapy. Informację uzupełnia wykaz prezentowanych na mapie krain oraz wybranych w nich miast, których położenie geograficzne oznaczono miarą mak-
Pewną ciekawostką dla czytelnika może być stosowany przez Nicolausa sposób zapisu oznaczeń współrzędnych geograficznych - zamiast stopni i minut użył on stopni i ich części zapisanych w postaci ułamka zwykłego, np. „55 1/2”, co należy odczytać jako $55^{\circ} 30^{\prime}$ (lub według systemu zapisu w Google $\left.-55.50^{\circ}\right)$. Inny przykład: $561 / 21 / 4^{\circ}$ należy czytać $561 / 2$ plus $1 / 4$, co oznacza 56 stopni $30^{\prime}$ plus $15^{\prime}=56^{\circ} 45^{\prime}$ itd. Należy również pamiętać, że wszystkie oznaczenia długości geograficznej $(\lambda)$ za czasów Ptolemeusza i Nicolausa były liczone na wschód od południka przechodzącego przez Ferro. Cytując zapis współrzędnych geograficznych w niniej-

\footnotetext{
${ }^{44}$ W literaturze spotyka się określenie „siatka Germanusa” dla oznaczenia wersji siatki Ptolemeusza zastosowanej przez Nicolausa.

${ }^{45}$ Na mapie Prima europe tabula Nicolaus uzasadnia swój wybór sposobu prezentacii.

${ }^{46}$ „Differentia partis superioris ad inferiorem tabule in studiis[stadiis] siquidem 2340 in miliaribus uero 250. Ergo pro commoditate atque operis precisione sic fieri oportuit".

${ }^{47}$ Jest to inny niż przez podanie explicite długości geograficznej sposób zapisania odległości kątowej, używany zarówno przez kartografów starożytnych, jak i nowożytnych działających w obszarze basenu Morza Śródziemnego.
} 
szej publikacji, nawiązano do oryginalnego zapisu, ale przy skomplikowanych przeliczeniach pierwotny zapis uzupełniono o zapewne dogodniejszy dla dzisiejszego odbiorcy sposób.

Znakomita większość katalogów opisujących mapy regionalne Ptolemeusza nie podaje ich skali ${ }^{48}$. Związane jest to przede wszystkim z brakiem dostępu do oryginalnych kopii. Tylko pracując na materiałach źródłowych można dokonać stosownych pomiarów, a następnie obliczeń. Zatem na potrzeby artykułu objaśniono sposób, w jaki policzono skalę „zamierzoną" mapy całej ekumeny ${ }^{49}$, w której Nicolaus chciał narysować pomniejszenie obrazu znanej mu Ziemi. Dane matematyczne do takiego przeliczenia przekazał sam Nicolaus Germanus. Wykonano więc obliczenie
96,4 km. Druga wartość, którą zapisał Nicolaus na dwóch mapach ${ }^{51}$, brzmi „Vnus gradus sub equinostiali continet miliaria $62 \frac{1 / 2}{2}$ " i pozwala na wyliczenie długości $1^{\circ} \lambda=92,4 \mathrm{~km}$ (przy założeniu, że 1 mila rzymska $=1478,5 \mathrm{~m}$ ).

Za czasów Nicolausa uważano, że Ziemia jest idealną kulą. Kierując się tym, można było przyjąć, iż $1^{\circ} \varphi$ (szerokości geograficznej) także odpowiada około 96,4 km lub 92,4 km. Średnia arytmetyczna tych dwóch liczb wynosi $94,4 \mathrm{~km}$. W ten sposób uzyskano oznaczenie pomniejszenia obrazu ekumeny około 1:38 000000 . Na bocznych ramkach wszystkich dwudziestu pięciu map ptolemejskich oraz na mapie Europy Północnej Nicolausa oznaczona jest szerokość geograficzna i opisana co jeden stopień, a na mapie świata i Afryki

(a)

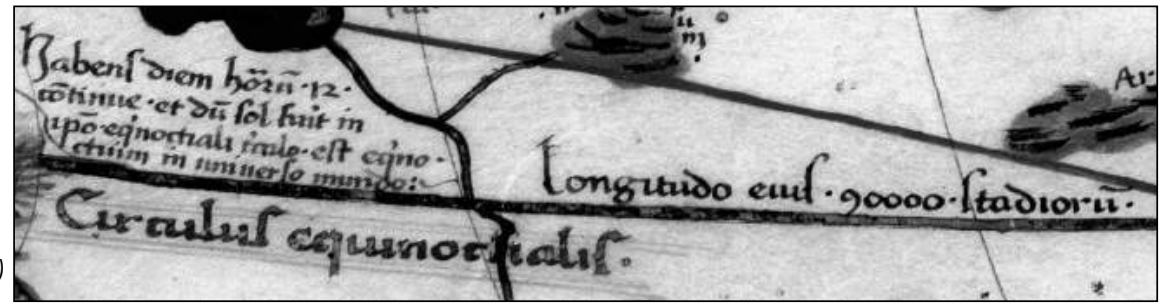

(b)

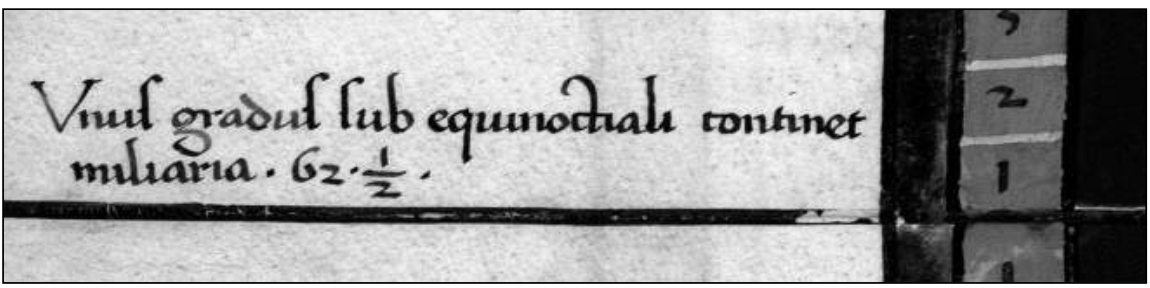

Ryc. 7. Podziałki mianowane, zapisane na równiku ziemskim przez Nicolausa na mapach: (a) „Świata”, (b) „Azji na wschód od Gangesu”

na podstawie zapisu, który Nicolaus umieścił na mapie świata (ryc. 7), gdzie oznaczył długość równika słowami: „Circulus equinoctialis Habens diem horum 12 continue" (równik mający dzień długości 12 godzin) oraz dalej: „longitudo eius 90000 stadiorum” (jego długość wynosi 90000 stadionów $\left.^{50}\right)$. Przyjmując, że 1 stadion olimpijski $=192,8 \mathrm{~m}$, otrzymano ok. $17352 \mathrm{~km}$ jako długość części równika obejmującej na mapie $180^{\circ}$ długości kątowej. $\mathrm{Z}$ tego prostego rachunku wynika, że kąt $1^{\circ} \lambda$ (długości geograficznej) odpowiada około
- co pięć stopni. Ponadto na górnym lewym marginesie każdej mapy Nicolaus zapisuje długość jednego stopnia długości geograficznej na

\footnotetext{
${ }^{48}$ Zob.: L. Szaniawska, Sarmacja na mapach Ptolemeusza...; ; w opisie każdego pierwszego wydania mapy Sarmacji i Germanii podaję ich przybliżone skale.

${ }^{49}$ Obliczone skale pozostałych map podano w tab. 2.

${ }^{50}$ Polską nazwę „stadion” użyto za: Vademecum historyka starożytnej Grecji i Rzymu, t. 1, Warszawa 1982, s. 338, gdzie autorzy piszą 0 miarach greckich 1 stadion $=600$ stóp.

${ }^{51}$ Zapis długości $1^{\circ} \lambda$ występuje na mapach Quarta \& ultima Africe tabula i Undecima Asyae tabula.
} 
danej szerokości geograficznej, czyli oznacza podziałkę mianowaną, którą zastosował przy konstruowaniu każdej opracowanej przez siebie ramki mapy. Również opisane na ramce każdej mapy regionalnej stopnie szerokości geograficznej mogą z powodzeniem posłużyć do obliczenia dla każdej mapy wielkości pomniejszenia prezentowanego przez nią obrazu w stosunku do rzeczywistego. Jednak należy pamiętać, że podana tutaj skala to tylko zamierzona i rozmiary obrazowanych lądów nie za-

(a)

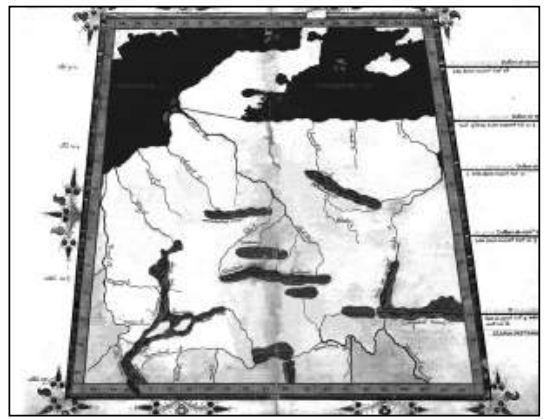

(b)

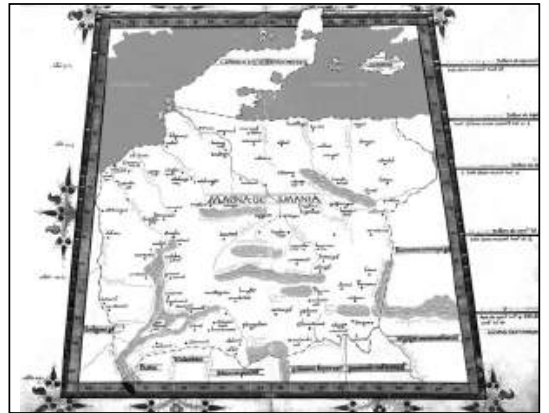

(c)

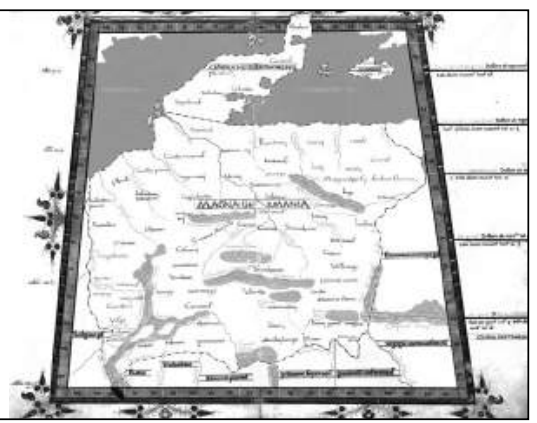

Ryc. 8. Wersje mapy Germanii z wybranymi elementami treści: (a) rzekami, górami i lasami; (b) siecią miejscowości; (c) nazwami ludów (opracowat J.A. Szaniawski) wsze odpowiadają rzeczywistym. Szczególnym przykładem są rozmiary Cejlonu na mapie DVODECIMA \& ultima Asiae tabula continet taprobanem insulam (...), które w żaden sposób nie odzwierciedlają rzeczywistości.

Ilość i jakość danych geograficznych naniesionych na poszczególne mapy zależy od stopnia poznania opisywanego regionu. Wiedza starożytnych geografów w tym względzie w zasadniczy sposób różniła się od dzisiejszej. Poniższa analiza porównawcza gęstości infor-

(a)

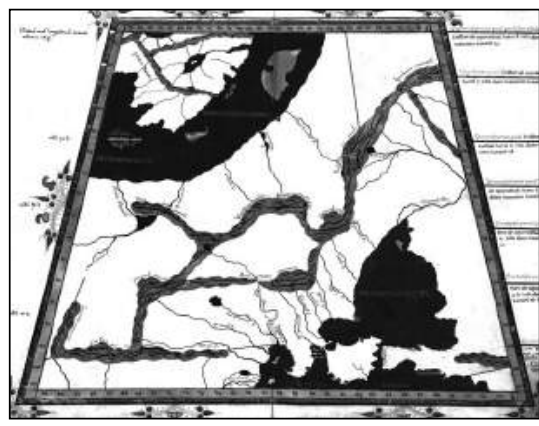

(b)

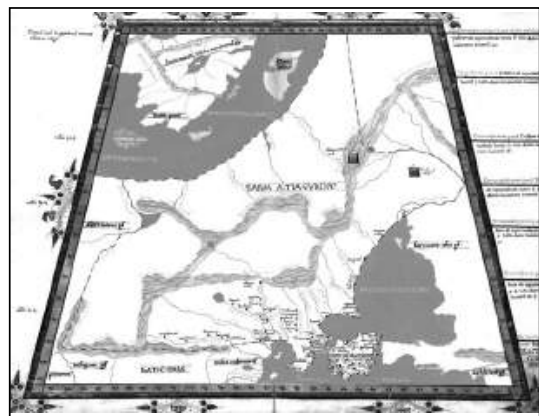

(c)

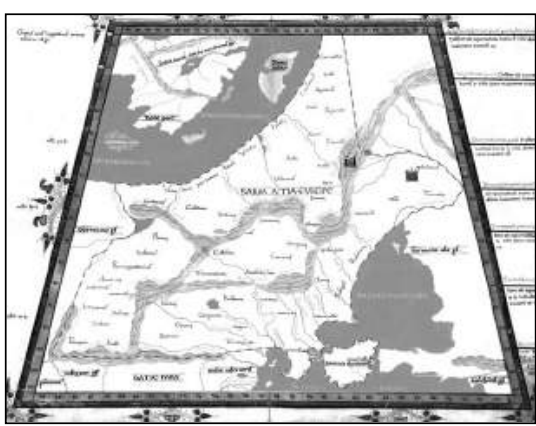

Ryc. 9. Wersje mapy Sarmacji Europejskiej z wybranymi elementami treści: (a) rzekami i górami; (b) siecią miejscowości; (c) nazwami ludów (opracował J.A. Szaniawski) 
macji tworzących treść geograficzną map, prezentujących Germanię i Sarmację Europejską (ziemie I Rzeczypospolitej i europejskiej części Rosji), jest dobrym przykładem kartograficznego przekazania danych geograficznych Ptolemeusza dla obszarów należących do imperium rzymskiego oraz terenów odeń oddalonych. Przylegające do siebie obszary Germanii i Sarmacji Europejskiej zostały narysowane w zbliżonej skali. Pomaga to w formułowaniu wniosków wynikających z analizy. Ptolemeusz, a za nim Nicolaus, dokonali ilościowego i jakościowego doboru obiektów geograficznych, uzyskując pewien określony stopień gęstości rysunku. Porównanie stopnia szczegółowości obu map, przez analizę wybranych elementów środowiska naturalnego, takich jak hydrografia i orografia (ryc. 8a, 9a), pozwala wysnuć wniosek, że geografowie ci utworzyli z nich dość równomierny na całej powierzchni mapy podkład dla informacji na temat elementów o charakterze antropogenicznym. Jeśli dokonamy na mapach Germanii i Sarmacji niewielkiego zabiegu graficznego, polegającego na usunięciu rysunku rzek, jezior, mórz, lasów i pasm górskich, uzyskamy bardzo czytelny obraz tych właśnie elementów. Dla obszarów Germanii mamy nazwy kilkudziesięciu ludów (ryc. 8c) oraz sieć osadniczą składającą się z ponad stu miast i osiedli (ryc. 8b). Obraz ten odzwierciedla wiedzę starożytnych geografów, powtórzoną przez Nicolausa za poprzednimi kopistami tekstu i map, o tym - położonym w pobliżu granic imperium rzymskiego - regionie.

Całkiem odmienny charakter od równomiernej sieci osadniczej Germanii ma osadnictwo przedstawione na mapie Sarmacji Europejskiej (ryc. 9). Znajdujemy tu 23 nazwy miast w południowej części Sarmacji (głównie wzdłuż dolnych biegów większych rzek) oraz 21 na Krymie $^{52}$. Ta stosunkowo gęsta sieć osadnicza na południowo-wschodnich krańcach Sarmacji była skutkiem rozpoczętej jeszcze w VI w. p.n.e. kolonizacji greckiej. Pozostałe terytorium tego regionu jest całkowicie pozbawione nazw miejscowości (ryc. 9b). Rolę oznaczenia osadnictwa na mapie tej części Sarmacji przejęły równomiernie rozmieszczone nazwy ludów (ryc. 9c).
Nicolaus mógł dokonać takiego zabiegu, gdyż w tekście traktatu Ptolemeusz podał położenie ludów jedynie relatywnie, w stosunku do innych obiektów geograficznych, takich jak rzeki i góry. Podobne obrazowanie osadnictwa zostało zastosowane na mapach regionów Sarmacji Azjatyckiej, Scytii i Regio Serica, na których - by zapełnić puste przestrzenie - dodano legendarne lub fikcyjne nazwy, m.in. Hippophagi Scithe (Scytowie koniożercy), Antropophagi Scite (Scytowie ludożercy) itp.

Redagując mapy do Geografii, Nicolaus Germanus nie narysował zbiorczej tablicy objaśniającej zastosowanie znaków graficznych do prezentacji obiektów geograficznych na mapie. W średniowieczu i na początku renesansu w zasadzie nie tworzono legend do map geograficznych. Posługiwano się intuicyjnie zrozumiałymi dla odbiorców znakami, które dziś też nie budzą większych wątpliwości co do ich znaczenia. Nicolaus użył całej palety znaków - powierzchniowych, liniowych i punktowych - stosowanych z niewielkimi modyfikacjami na mapach ogólnogeograficznych do końca XVIII w. (tab. 3).

Prezentowany na każdym arkuszu mapy Nicolausa obszar podzielony został na dwie kategorie - obszar należący do danego regionu i tereny poza jego granicami. Ten drugi obszar, oddzielony od prezentowanego regionu granicami naturalnymi (poprowadzonymi rzekami, wybrzeżami, rzadziej pasmami górskimi) lub sztucznymi, zaznaczonymi czerwoną kreską, był obrazowany z wyraźnie mniejszą szczegółowością (sprawia wrażenie pustego). Nie uwzględniono większości miast, rysowano tylko największe rzeki lub pomijano je, zaś nazwę obszaru wyróżniano napisem pokrytym zaledwie płatkami srebra, mniej wykwintnymi niż płatki złota, którymi zdobiono nazwę głównego regionu. Ten sam teren na innej mapie, jeśli znalazł się w obrębie prezentowanego regionu, był rysowany z większą szczegółowością. Do-

\footnotetext{
${ }^{52}$ Obszerniejsze omówienie toponimów obszaru Sarmacji Europejskiej w: H. Łowmiański, Studia nad dziejami Stowiańszczyzny, Polski i Rusi w wiekach średnich. Poznań 1986, s. 43-53 oraz Penelope online, Chapter 5, Location of European Sarmatia (from the Eighth Map of Europe), (dostęp: http://penelope.uchicago.edu/Thayer/E/Gazetteer/Periods/Roman/_Texts/Ptolemy/3/5*.html, 17 marca 2013).
} 
Tabela 3. Przykłady sposobów prezentacji obiektów geograficznych przez Nicolausa Germanusa

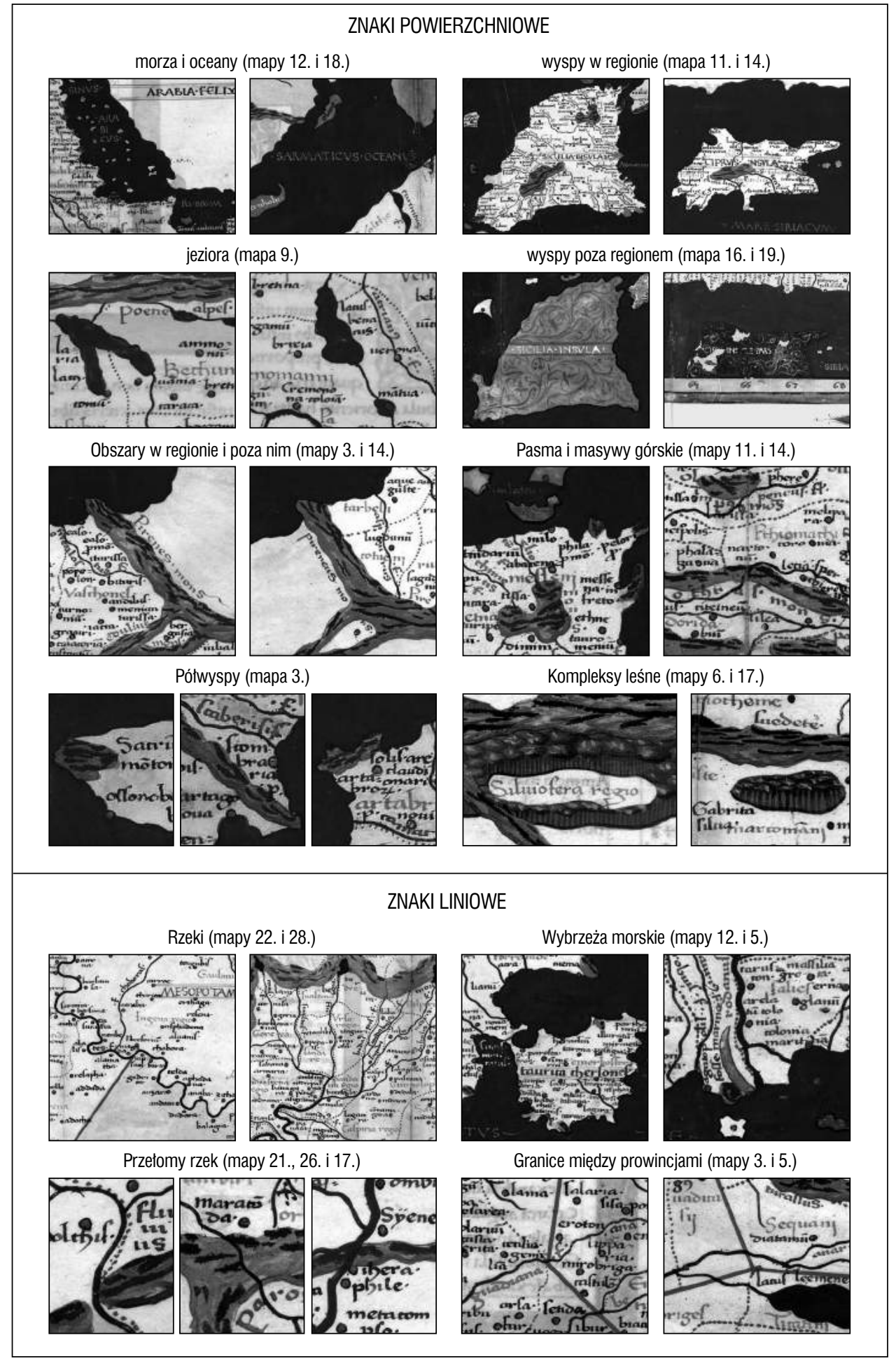




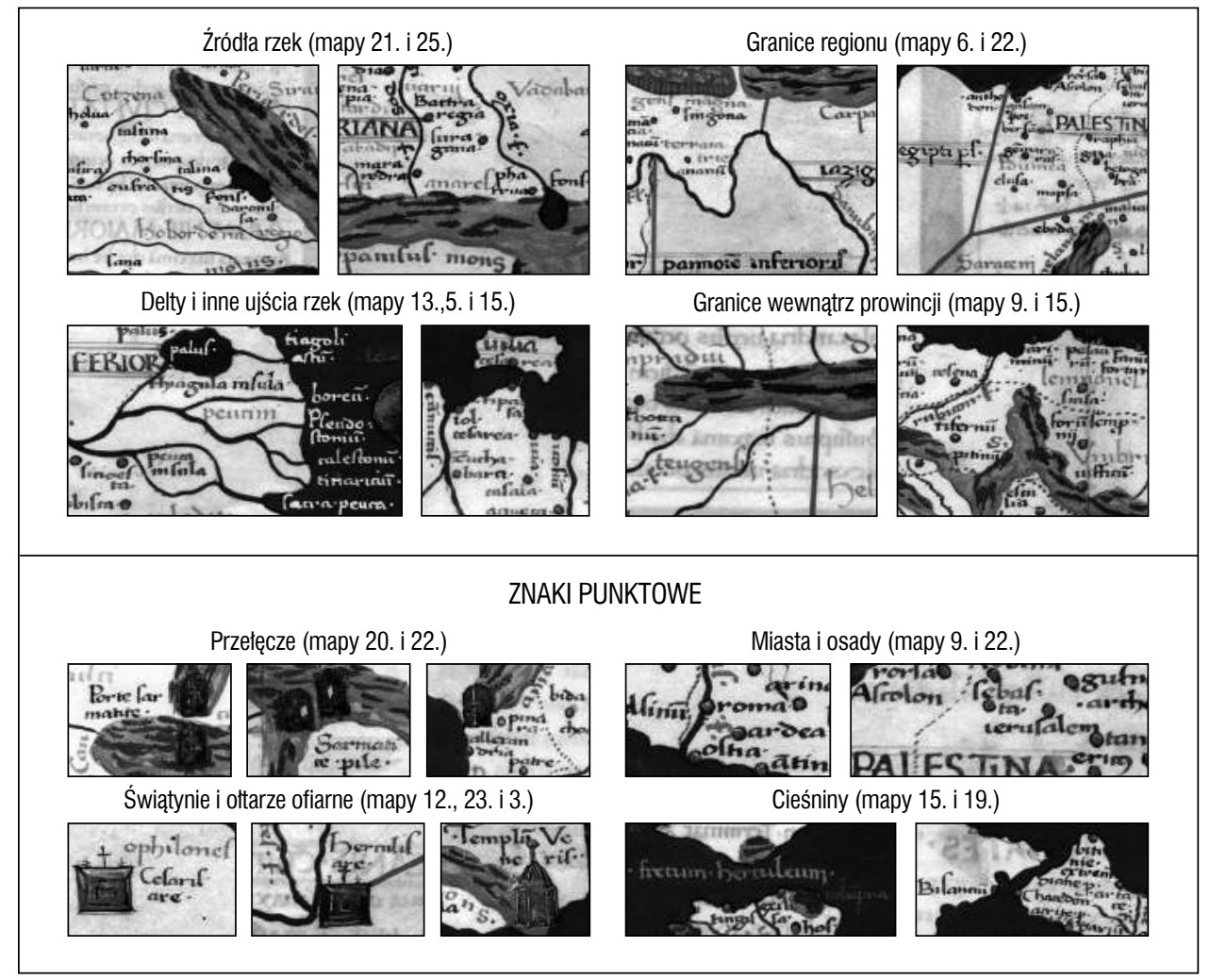

brą ilustracją tej konwencji jest przykład obrazowania Półwyspu Apenińskiego na mapie 9 (SEXTA europe tabula) oraz na mapie Krain nad Morzem Adriatyckim 8 (QVINTA europe tabula). Na tej drugiej jedynym wyraźnie widocznym toponimem w Italii jest „ITALIE PARS”, poza tym półwysep jest w zasadzie pozbawiony nazw geograficznych i rysunku terenu. W podobny sposób różni się rysunek Krymu na mapach Sarmacji Europejskiej 12 (OCTAVA [Europae] tabula) i Azjatyckiej 20 (SECVNDA asiae tabula) (ryc. 10).

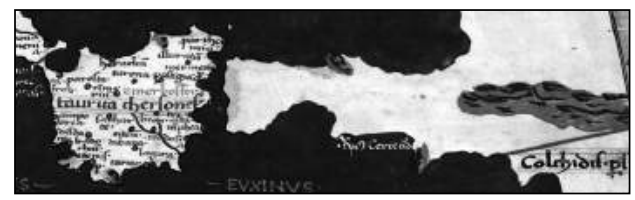

(a)
Z podobną sytuacją, choć inaczej oddaną graficznie, mamy do czynienia w przypadku wysp Sardynii i Sycylii, których obszar na mapie 16 (SECVNDA africae tabula continet africam \& insulas que circa ipsam sunt) prowincji Afryki Prokonsularnej oraz na mapie 9 (SEXTA europe tabula Italiam continet \& cyrnum insulam<...>) Półwyspu Apenińskiego - w tym drugim przypadku jedynie obszar Sardynii - wypełniono jednolicie farbą $\mathrm{z}$ dodaniem ładnego ornamentu, ale bez umieszczenia na nim treści geograficznej. Obie te wyspy zaś zaprezentowano

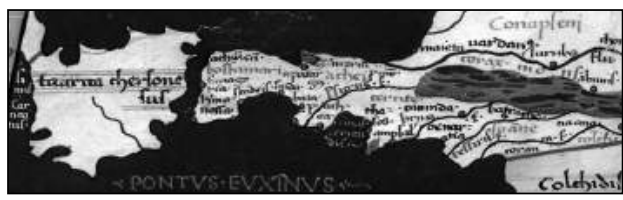

(b)

Ryc. 10. Zestawienie szczegótowości obrazu Krymu na mapie (a) Sarmacji Europejskiej i (b) Sarmacji Azjatyckiej 
„W pełnej krasie” dopiero na poświęconej im mapie 11 (SEPTIMA europe tabula continet Sardiniam \& Siciliam insulas).

Spośród sygnatur obrazkowych na uwagę zasługują winietki prezentujące przełęcze górskie oraz świątynie i ołtarze ofiarne (tab. 3). Pierwsze oznaczono solidnie okutymi bramami, drugie natomiast wyróżniono kompozycjami kolumn, ołtarzy lub budowli przypominających latarnie. Niektóre jednak z nazwanych na mapie świątyń pozostawiono bez winietki, podobnie stało się z przełęczami i przełomami rzek, jak np. przełom Tygrysu, który wcina się wyraźnie pomiędzy góry „Thaurus Mons” oraz „Niphates Mons”.

Aby podkreślić wagę informacji o wybranych obiektach w terenie, do graficznej kompozycji map wykorzystano intensywne kolory: biały, pomarańczowy, żółty, czerwony, różowy, zielony (z malachitu), niebieski (z azurytu), zło- to i srebro (kładzionych na zaprawę w postaci płatków lub farb przygotowywanych z prosz$\mathrm{ku}$ ze spoiwem). Wraz z rysunkiem warstwa malarska tworzy pełny merytorycznie i komunikacyjnie obraz. Akweny morskie, jeziora, a także rzeki pokryto grubą warstwą niebieskiej farby. Obszary górskie pokryto kolorem brązowym w kilku nasyceniach barwy, kompleksy leśne - zielonym, zaś powierzchnie wysp różnymi kontrastującymi $\mathrm{z}$ sobą kolorami. Nazwy mórz, rzek, regionów, krain, miejscowości oraz plemion zapisano zróżnicowanym pod względem rodzaju i wielkości pismem, ale jednakowym w ramach tej samej kategorii. Do zapisu nazw regionów, prowincji i krain zastosowano odpowiedniej wielkości złotą lub srebrną majuskułę i minuskułę. Nazwy innych kategorii obiektów zapisano jedynie minuskułą, różnicując ją jednak zmianą kolorów. Do nazw miejscowości użyto brązowego

\section{Tabela 4. Przykłady zapisu nazw geograficznych i zastosowanych abrewiatur i duktu pisma}

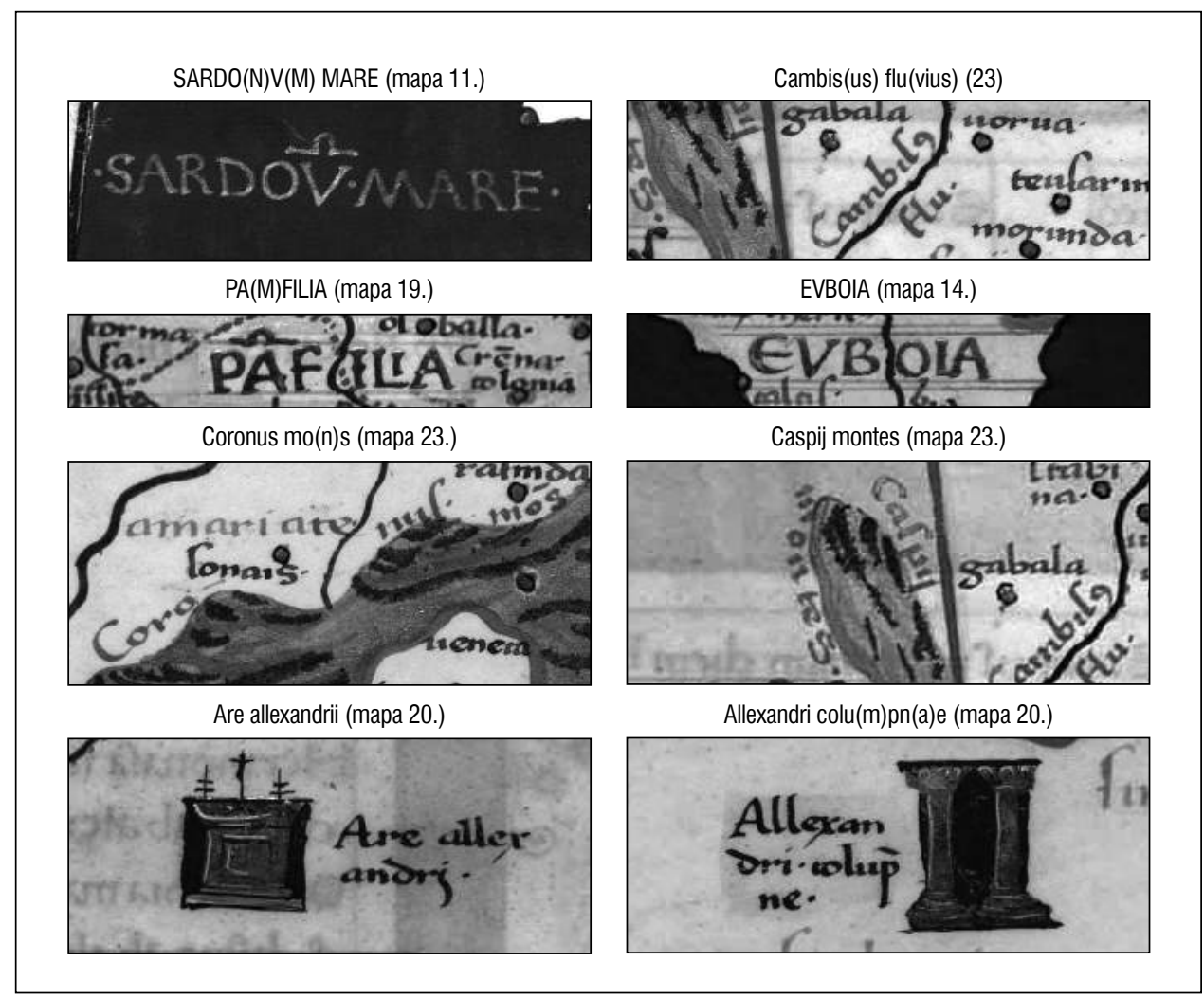


atramentu ${ }^{53}$, do nazw rzek oraz granic największych regionów - koloru czerwonego, do nazw ludów i mniejszych krain oraz ich granic - koloru różowego, do pasm górskich - koloru zielonego, zaś nazwy kompleksów leśnych zapisano kolorem brązowym (tab. 4).

Zarówno w tekście ośmiu ksiąg, jak i na mapach, Nicolaus używał skrótów - abrewiatur stosowanych powszechnie przez skrybów działających na przełomie średniowiecza i renesansu. Szczególnie wiele skrótów zastosował w nazwach geograficznych, pisząc je na mapie w miejscach, gdzie do odnotowania było wiele toponimów, a mało miejsca. Zdarzają się przypadki, że poszczególne fragmenty jednego słowa mieszają się lub zachodzą jedne na drugie. Część nazw, zwłaszcza rzek i gór, rozdzielona została rysunkiem innych obiektów.

$\mathrm{Na}$ zakończenie uwag dotyczących grafiki map i towarzyszących im tekstów, należy wspomnieć o bogatych zdobieniach ramek i marginesów. Zewnętrzne pasy ramki wszystkich map pokryto płatkami złota, niektóre $\mathrm{z}$ nich, np. mapy świata, zdobiąc złote powierzchnie ornamentami wykonanymi transparentną substancją. Marginesy map, podobnie jak marginesy tekstów na verso map, ozdobiono w narożnikach motywami roślinnymi tworzącymi indywidualne kompozycje, niepowtarzane na innych kartach traktatu (ryc. 11a), ale po- mieszczona mapa DVODECIMA \& ultima Asiae tabula (Dwunasta mapa Azji). Po prawej stronie karty umieszczony jest spis regionów zatytułowany PROVINTIE NOBIS NOTE (Znane nam prowincje), po którym traktat kończy się następującymi słowami: „CLAVDII PTHOLOMEI VIRI ALLEXANDRINI COSMOGRAFIE VIII ET VLTIM(us) LI(ber) EXPLICIT".

\section{Zakończenie}

Pierwszą konsekwencją przyjęcia ptolemejskich zasad matematycznych rysowania map oraz zapoznania się z sugestywnymi redakcjami map Nicolausa Germanusa było stopniowe zaprzestanie rysowania mappae mundi, których skala pomniejszenia obrazu, przeniesienie z powierzchni kulistej na płaską oraz rozmieszczenie obiektów geograficznych, nie było oparte na obliczeniach matematycznych, a jedynie na intuicji twórcy map. Ostatnią i najwspanialszą z nich była mapa mnicha Fra Maura narysowana w 1459 r., zawierająca obok obiektów geograficznych także obiekty o charakterze etnograficznym i legendarnym. Umownie można przyjąć, że rok 1460 był końcem mappae mundi, i początkiem redagowania map według matematycznych zasad wyjaśnionych przez Ptolemeusza w Geografii. Prezentowana ekumena nadal obejmowała obszary od Wysp Ka-

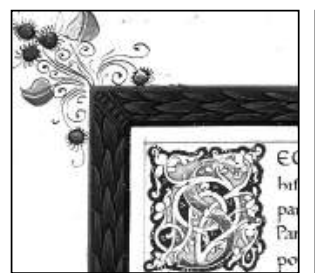

(a)

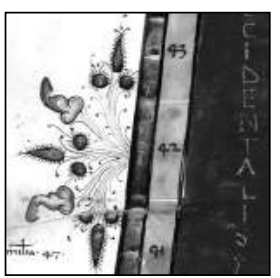

)

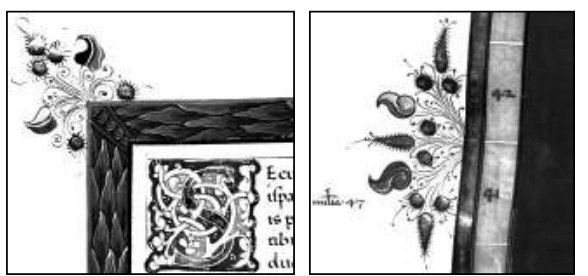

(b)

Ryc. 11. Ornamenty roślinne oraz bordiury na mapie Pótwyspu Pirenejskiego i na jej verso w kopiach: (a) Warszawa, BN; (b) Florencja, BML

dobne do użytych w innych kopiach Geografii wykonanych przez Nicolausa, np. w kopii przechowywanej we Florencji w Biblioteca Medicea Laurenziana, Plut. 30.03.

Jako ostatnia prezentacja kartograficzna w redakcji Nicolausa Germanusa została za- naryjskich na zachodzie po Tartarię na wschodzie, od Wyspy Thule na północy po Indie, środkową Afrykę na południu, jednak treścią

\footnotetext{
${ }^{53}$ Wyraźnie obecnie brązowy atrament, którym zapisano nazwy miejscowości oraz tekst w księgach traktatu mógł w przeszłości być czarny.
} 
map stały się li tylko obiekty ściśle geograficzne, czyli rzeki, jeziora, morza, góry, miejscowości, państwa, krainy i terytoria oznaczane nazwą ludów, bez dołączania legendarnych krain jak - Raj, Gog i Magog. Mapy zyskały charakter map ogólnogeograficznych na uporządkowanym informacyjnym poziomie mapy przeglądowej, a komponowane $\mathrm{z}$ nich atlasy zawierały zwykle mapę znanego świata i zbiór map regionalnych.

Najwcześniejsze, tworzone na podobieństwo Geografii Ptolemeusza w redakcji Nicolausa, renesansowe zbiory map, które historycy kartografii nazwali atlasami (dokładniej - composite atlases), były publikowane $\mathrm{w}$ Rzymie i w Wenecji. Takie zbiory map różnych twórców i formatów były pewnym rodzajem renesansowej kartograficznej „antologii”, składającej się z map dobranych według określonych zasad i opatrzonych drukowaną kartą tytułową. Były publikowane jako oprawny zbiór map, ale także jako pojedyncze mapy. Jednym z najwcześniejszych ich twórców był Burgundczyk Antonio Lafreri, działający w Rzymie w latach 1540 1577. Współpracując od 1553 r. z antykwariuszem Antonio Salamanką, później z Francesco Salamanką, stworzyli największąi i najprężniejszą księgarnię na rynku zdominowanym przez odbitki miedziorytnicze planów miast, map i planów bitew rozegranych $\mathrm{w}$ różnych miejscach

\section{Literatura}

L'Atlante di Borso D'Este. La Cosmographia della Biblioteca Estense Universitaria di Modena, commentario all'edizione in facsimile del codici miniato cl.X.1.3 = Lat. $463 /$ testi di Laura Federzoni, Annalisa Battini, a cura di Mauro Bini. Modena: Il Bulino edizioni d'arte, 2006.

Babicz J., Donnus Nicolaus Germanus: Probleme seiner Biographie und sein Platz in der Rezeption der Ptolemäischen Geographie, München 1980.

Babicz J., The Celestial and Terrestrial Globes of the Vatican Library Dating from 1477, and their Maker Donnus Nicolaus Germanus (ca. 1420-ca. 1490), „Der Globusfreund”, 1987 , nr 35-37, s. 155-168. całej Europy. Najczęściej pojawiającym się na mapach sprzedawanych przez Lafreriego był sygnet kosmografa Republiki Weneckiej Giacomo Gastaldiego, który opracował nie mniej niż 109 map opublikowanych techniką miedziorytniczą. W latach sześćdziesiątych rozpoczęli jako kolejni działalność edytorską księgarze, wydawcy i miedziorytnicy weneccy, spośród nich należy wspomnieć o najaktywniejszych, jak: Paolo Forlani (lata działalności 1560-1571), Gioan Francesco Camocio (lata działalności w Wenecji 1560-1566), Giovanni Paolo Cimerlino (około 1565), Fabio Licinio, malarz i drukarz Fernando Bertelli (lata działalności 1564-1572) i Donato Bertelli (lata działalności 1568-1574), rytownik Domenico Zenoi czy Bolognino Zaltieri (lata działalności 1555-1576).

Kolejnym krokiem w rozwoju opracowywania zbiorów map, później nazwanymi atlasami, było zastosowanie wspólnych reguł redagowania wszystkich map włączanych do konkretnej publikacji atlasu. Zasłynęli z nich antwerpscy (Abraham Orteliusz, Gerard de Jode), amsterdamscy (Jodocus Hondius, Johannes Janssonius, Joan Blaeu) oraz inni twórcy i wydawcy tego typu publikacji geograficznych. Oni także redagowali mapy oraz atlasy na wzór Geografii Ptolemeusza w redakcji Nicolausa ${ }^{54}$.

Nicolaus Germanus, w: The Catholic Encyclopedia, red. C.G. Herbermann i in., t. 11, New York 1911.

Dalché P.G., The Reception of Ptolemy's "Geography" (End of the Fourteenth to Beginning of the Sixteenth Century), w: The History of Cartography, Cartography in the European Renaissance, Part 1, red. D. Woodward, ChicagoLondon 2007, s. 285-364.

${ }^{54}$ L. Szaniawska, Popularyzacja regut kartograficznych Ptolemeusza w renesansowych atlasach świata Orteliusa, Mercatora i De Jode, w: Z Dziejów Kartografii, Od atlasu do kolekcji. W 440. rocznicę I wydania atlasu Abrahama Orteliusa, t. 16, Szczecin 2011 , s. 87-99. 
Clavdii Ptolemaei Geographiae codex Vrbinas graecvs 82: Tomvs prodromvs Josephi Fischer, S.J., De Cl. Ptolemaei vita, operibvs, geographia praesertim eivsque fatis. Pars prior. Commentatio. Lvgdvni Batavorvm, apud E.J. Brill; Lipsiae, apud Ottonem Harrassowitz, 1932, w: Codices e Vaticanis selecti ; 19. 2 v. w 4 (635 s.).

Klaudios Ptolemaios Handbuch der Geographie. Griechisch - Deutsch, red. A. Stückelberger i in., Basel 2006.

Klaudios Ptolemaios Handbuch der Geographie. Ergänzungsband mit einer Edition des Kanons bedeutender Städte, red. A. Stückelberger i in., Basel 2009. Joachima Lelewela badania starożytności we względzie geografji: część naukowa, Wilno-Warszawa 1818.

Łowmiański H., Studia nad dziejami Stowianszczyzny, Polski i Rusi w wiekach średnich, Poznań 1986.

Nordenskiöld A.E., Facsimile Atlas to the early history of cartography. with reproductions of the most important maps in the XV and XVI centuries, translated from the Swedish original by J.A. Ekelof and C.R. Markhaln. Reprint z wyd. Stockholm 1889, New York 1973.

Raidel G.M., Commentatio critico-literaria de Clavdii Ptolemaei Geographia, eivsque codicibvs tam manv-scriptis quam typis expressis, conscripta a Georgio Martino Raidelio (...). Norimbergae: typis et sumtibus haeredum Felseckerianorum, 1737.

Mittenhuber F., Text-und Kartentradition in der "Geographie" des Klaudios Ptolemaios.
Eine Geschichte der Kartenüberlieferung vom ptolemäischen Original bis in die Renaissance, Bern 2009.

Szaniawska L., Sarmacja na mapach Ptolemeusza w edycjach jego "Geografii”, Warszawa 1993.

Szaniawska L., "Geografia” Ptolemeusza prekursorskim zbiorem danych przestrzennych, $\mathrm{w}$ : Bazy danych $w$ kartografii, pod red. W. Żyszkowskiej i W. Spallka, Wrocław 2009, s. 130-153.

Szaniawska L., Popularyzacja regut kartograficznych Ptolemeusza $w$ renesansowych atlasach świata Orteliusa, Mercatora i De Jode, w: $Z$ Dziejów Kartografii, Od atlasu do kolekcji. W 440. rocznice I wydania atlasu Abrahama Orteliusa, t. 16, Szczecin 2011, s. 87-99.

Katalog, oprac. L. Szaniawska, w: Świat Ptolemeusza, wtoska kartografia renesansowa w zbiorach Biblioteki Narodowej. Wystawa $w$ stulecie urodzin Jana Zamoyskiego, Warszawa 2012, s. 72-255.

Die Ulmer Geographia des Ptolemäus von 1482. Zur 500. Wiederkehr der ersten Atlasdrucklegung nördlich der Alpen, Ausstellung und Katalog: K.H. Meine; Ulm, Schwörhaus 11. Oktober bis 30. November 1982, Weißenhorn 1982.

Vademecum historyka starożytnej Grecji i Rzy$m u$, t. 1, oprac. B. Bravo i in., red. E. Wipszyckiej, Warszawa 1982.

Wielka historia świata, t. 3. Świat okresu cywilizacji klasycznych, pod red. nauk. A. Krawczuka i in., Warszawa 2005.

\section{Principles of a geographic description and map drawing in Geography by Ptolemy edited by Nicolaus Germanus - a manuscript BOZ 2}

\section{Summary}

A hand-written geographical treaty Codex in Bibliotheca Zamoiskiensi Latinus BOZ 2, edited by a Benedictine Nicolaus Germanus, is kept as a deposit in the National Library in Warsaw. It consists of two separate parts: the text on 80 sheets of paper in a folio format and a collection of 30 maps, including 1 map of the world and 26 regional maps by Ptolemy as well as 3 „tabulae modernae”. The books with the text by Ptolemy were conscientiously copied by Nicolaus. The text includes geographic data together with the geographic coordinates and an explanation of the principles of Ptolemy's two map projections - the first useful in drawing regional 
maps, and the other used to edit a map of the whole world.

Ninety one chapters include geographic descriptions of particular regions. Book II includes descriptions of Europe, from its north-western parts from Ireland (k. 13vb) to Germania reaching the Vistula in the east. The descriptions of book III include geographic information concerning eastern and south-western Europe from the Apennine Peninsula (k. 24vb), across Sarmatia to Greece. Book IV includes data on Africa from which information to the maps was taken. It begins with a description of Mauretania (k. 36va) reaching the Pillars of Hercules in the west, and closes with a description of Egypt. The fourth map covers all Africa as known in ancient times as far as the Mountains of the Moon lying south of the equator. Book $\mathrm{V}$ begins with a description of Asia, with the region of Pontus (k. 41ra), across Asian Sarmatia and the countries of the Near East together with the Arabian Peninsula as far as Babylonia. Book VI discusses the countries of Central Asia: from Assyria (k. 55ra), across the regions of the South Caucasus as far as Persia and the regions dominated by the latter. In book VII, Ptolemy included information concerning south-eastern and eastern Asia: from India (k. 62va) as far as China and the Indonesian Islands as well as Taprobane island (end of description k. 67va). Book VII is finished with Epilogus (k. 69rb-69va).

Maps constitute the second, physically separate, part of the treaty. Twenty six regional (chorographic) maps edited on the basis of geographic data included in books II-VII constitute a collection intended by Ptolemy as showing all known lands, including those that were only mentioned in the works of other ancient writers. A consequence of different scopes of the maps was the use of different degrees of reduction of the projected area. The territory of the Roman empire and the other parts of Europe were shown in a similar scale, while far-off lands, especially those situated in east Asia, were reduced three times in relation to the maps of the European regions.

Ptolemy, and then Nicolaus, made a quantitative and qualitative selection of geographic objects, thus achieving a certain definite degree of the picture density. A comparison of the degree of particularity on the maps of Germania and Sarmatia through the analysis of selected elements of the natural environment such as hydrography and orography allows to draw the conclusion that those geographers created on the whole surface of the map a relatively even foundation for the elements with anthropogenic character - a network of localities and distribution of peoples.

Against the background of presentations of the world known at that time which were contemporary to Nicolaus Germanus or earlier, his presentation of Ptolemy's geographic data was - despite certain faults - much better than others. It should be admitted that Nicolaus was a conscientious interpreter of the writings of the Alexandrian scholar and, what is more, he won the trust of his contemporaries. The first printed versions of Geography appeared on the basis of his hand-written maps. Later editions usually differed with very small details or they were less successful.

Słowa kluczowe: historia kartografii, Klaudiusz Ptolemeusz, Nicolaus Germanus, Biblioteka Narodowa w Warszawie.

Keywords: history of cartography, Claudius Ptolemy, Nicolaus Germanus, National Library in Warsaw.

mgr Lucyna Szaniawska - Zakład Zbiorów Kartograficznych Biblioteki Narodowej, członek Zespołu Historii Kartografii przy Instytucie Historii Nauki PAN, (e-mail: lucyna-szaniawska@wp.pl). 